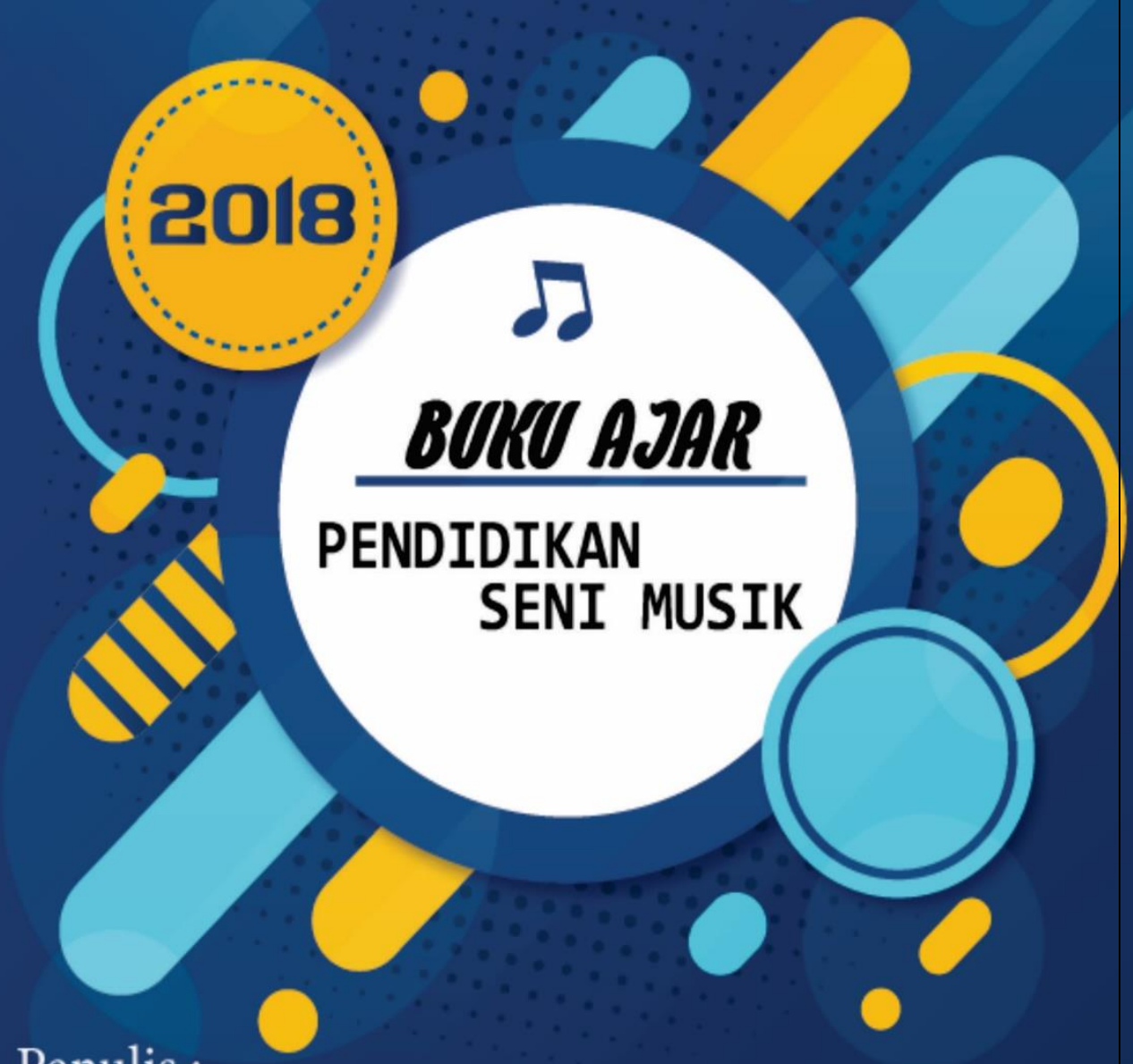

Penulis :

Evie Destiana, S.Sn., M.Pd 


\section{BUKU AJAR \\ PENDIDIKAN SENI MUSIK \\ (UNTUK MAHASISWA PGSD - PG-PAUD)}

Evie Destiana, S.Sn., M.Pd

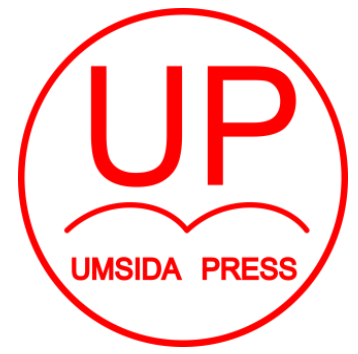

Diterbitkan oleh

\section{UMSIDA PRESS}

Jl. Mojopahit 666 B Sidoarjo

ISBN: 978-602-5914-02-7

Copyright@2018.

Authors

All rights reserved 


\section{BUKU AJAR}

PENDIDIKAN SENI MUSIK

(UNTUK MAHASISWA PGSD - PG-PAUD)

\section{Penulis :}

Evie Destiana, S.Sn., M.Pd

\section{ISBN :}

978-602-5914-02-7

\section{Editor :}

Septi Budi Sartika, M.Pd

M. Tanzil Multazam, S.H., M.Kn.

\section{Copy Editor :}

Fika Megawati, S.Pd., M.Pd.

Design Sampul dan Tata Letak :

Mochamad Nashrullah, S.Pd

\section{Penerbit :}

UMSIDA Press

\section{Redaksi :}

Universitas Muhammadiyah Sidoarjo

Jl. Mojopahit No 666B

Sidoarjo, Jawa Timur

Cetakan pertama, Agustus 2018

(C) Hak cipta dilindungi undang-undang

Dilarang memperbanyak karya tulis ini dengan suatu apapun tanpa ijin tertulis dari penerbit. 


\section{KATA PENGANTAR}

\section{Assalamu'alaikum Wr.Wb}

Musik merupakan bahasa yang tidak perlu diterjemahkan, namun dapat dinikmati dan dirasakan oleh semua usia. Dengan musik, kita dapat berekspresi tentang perasaan, menyampaikan ide, pesan dan banyak hal lainnya. Masa kanak-kanak merupakan masa paling menakjubkan, masa di mana dasar pertumbuhannya berkembang dengan pesatnya, dan musik dapat membantu anak dalam menerima pesan dan mengekspresikan perasaannya.

Pendidikan Seni Musik merupakan mata kuliah wajib yang harus ditempuh oleh mahasiswa PGSD dan PG-PAUD Universitas Muhammadiyah Sidoarjo, dan buku ini akan menjadi pegangan mahasiswa selama perkuliahan. Dengan mata kuliah ini, mahasiswa diharapkan mampu memahami tentang konsep musik, teori musik dasar dan praktek bermusik sebagai bekal bagi mahasiswa sebagai calon guru.

Dengan tersusunnya buku Pendidikan Musik Anak Usia Dini 1 ini dapat digunakan sebagai buku pegangan bagi mahasiswa untuk dapat lebih memahami tentang tujuan mata kuliah Pendidikan Musik Anak Usia Dini 1. Buku ini juga dilengkapi dengan partitur lagu anak-anak yang dapat menambah referensi lagu anak bagi mahasiswa PG-PAUD.

Puji syukur kehadirat Allah SWT, yang telah memberikan nikmatNya bagi kami sehingga buku Pendidikan Musik Anak Usia Dini 1 ini dapat tersusun dengan baik. Terima kasih kepada Dekan 
FKIP, Kaprodi PG-PAUD, LP3IK dan seluruh civitas akademika Universitas Muhammadiyah Sidoarjo yang telah memberikan kesempatan kepada kami. Semoga buku ini bermanfaat, segala kritik dan saran sangat kami harapkan untuk kebaikan semua di masa mendatang. Terima kasih.

Wassalamu'alaikum Wr.Wb 
DAFTAR ISI

\section{PRAKATA}

BAB I UNSUR-UNSUR MUSIK
A. Melodi
B. Tempo
1. Pengertian Tempo
2. Macam-macam Tanda Tempo
C. Irama
D. Timbre
E. Dinamika
1. Pengertian Dinamika
2. Macam-macam Tanda Dinamika
F. Pitch

BAB II BIRAMA DAN MENDIREKSI
A. Tanda Birama
1. Fungsi Tanda Birama
2. Macam-macam Tanda Birama
B. Mendireksi
1. Fungsi dan Tujuan Kegiatan Mendireksi
2. Gerakan Mendireksi

\section{BAB III NOTASI}
A. Notasi Angka
1. Menulis Notasi Angka
2. Membaca Notasi angka 
B. Notasi Balok

1. Menulis Notasi Balok

2. Membaca Notasi Balok

\section{BAB IV BERNYANYI UNTUK ANAK USIA DINI}
A. Pernafasan
B. Sikap Bernyanyi
C. Vocalizing Dasar
D. Bernyanyi

\section{BAB V MENGIRINGI}
A. Akord Prime
B. Akord Balikan
C. Mengiringi Lagu Anak Dengan 3 Akord Prime

DAFTAR PUSTAKA

\section{LAMPIRAN}




\section{BATANG TUBUH}

\section{BAB I}

Unsur musik (melodi, tempo, irama, dinamika, pitch, timbre)

Capaian Pembelajaran (CP) :
A. Mahasiswa memahami unsur musik
B. Mahasiswa dapat mendeskripsikan macam-macam unsur musik
C. Mahasiswa dapat mendeskripsikan fungsi unsur musik
D. Mahasiswa dapat menganalisis macam unsur musik dalam sebuah sajian musik

\section{BAB II}

Tanda sukat/ tanda birama dan mendireksi

Capaian Pembelajaran (CP) :

A. Mahasiswa memahami macam-macam tanda sukat/ birama

B. Mahasiswa memahami dan dapat mendeskripsikan fungsi tanda sukat/ birama

C. Mahasiswa memahami dan mendeskripsikan fungsi kegiatan mendireksi

D. Mahasiswa dapat mempraktekkan gerakan mendireksi sesuai sukat/ birama lagu 


\section{BAB III}

Notasi Angka

Capaian Pembelajaran (CP) :

A. Mahasiswa memahami fungsi notasi angka

B. Mahasiswa memahami dan mendeskripsikan tentang harga, nilai not dan tanda diam dalam notasi angka

C. Mahasiswa mampu membaca dan mengaplikasikan penulisan notasi angka dalam lagu

Notasi Balok

Capaian Pembelajaran (CP) :

A. Mahasiswa memahami fungsi notasi balok

B. Mahasiswa memahami dan mendeskripsikan tentang harga, nilai not dan tanda diam dalam notasi balok

C. Mahasiswa mampu membaca dan mengaplikasikan penulisan notasi balok dalam lagu 


\section{BAB IV}

Bernyanyi Untuk Anak Usia Dini

\section{Capaian Pembelajaran (CP) :}
A. Mahasiswa memahami fungsi bernyanyi untuk anak usia dini
B. Mahasiswa memahami dan mendeskripsikan teknik bernyanyi untuk anak usia dini
C. Mahasiswa mampu mengaplikasikan tehnik bernyanyi untuk anak usia dini

\section{BAB V}

Akord dan Mengiringi

Capaian Pembelajarn (CP) :
A. Mahasiswa memahami bentuk dan fungsi akord
B. Mahasiswa mendeskripsikan tentang akord
C. Mahasiswa mampu mengaplikasikan akord dalam instrumen harmoni
D. Mahasiswa mampu mengiringi lagu anak menggunakan 3 akord Prime


UNSUR-UNSUR MUSIK

Unsur-unsur musik merupakan bagian-bagian yang terkandung dalam musik dan menjadi satu kesatuan. Ada beberapa unsur yang terkandung dalam musik, melodi, tempo, ritme, dinamika, pitch dan timbre. Suatu bunyi-bunyian dapat dikatakan sebagai suatu sajian musik, meskipun hanya mengandung beberapa unsur saja, dan tidak semua unsur musik ada di dalamnya.

\section{A. MELODI}

Melodi adalah susunan rangkaian nada ( bunyi dengan rangkaian teratur) yang terdengar berurutan serta berirama dan mengungkapkan suatu gagasan pikiran dan perasaan (Jamalus, 1998 :16). Menurut faham musisi abad 18-19 yang masih diikuti sampai sekarang, melodi adalah suatu urutan yang utuh dan membawa makna. Adapun syaratnya ialah: berciri khas, berbentuk jelas, memuat suatu ungkapan dan dapat dinyanyikan ${ }^{1}$. Atau dalam bahasa lain bisa disebutkan bahwa melodi adalah rangkaian nada yang membentuk sebuah kalimat lagu. Melodi terdiri atas satu atau lebih frasa atau motif, dan diulang-ulang dalam satu lagu

\section{B. TEMPO}

Tempo musik adalah cepat lambatnya yang berkaitan erat dengan panjangnya hitungan dasar dalam musik. Secara garis besar,

${ }^{1}$ Pono Banoe, Kamus Musik.113 
tempo dibagi atas 3 bagian: lambat, sedang dan cepat. Alat yang digunakan untuk mengukur kecepatan dalam tempo disebut Metronome.

\section{Macam-macam Tanda Tempo:}

\begin{tabular}{|l|l|}
\hline Largo & Lambat sekali (40-60 hitungan/ menit) \\
\hline Adagio & Lambat (66-76 hitungan/ menit) \\
\hline Andante & $\begin{array}{l}\text { Lambat seperti berjalan kaki (76-108 } \\
\text { hitungan/ menit) }\end{array}$ \\
\hline Andantino & Lebih cepat dari andante \\
\hline Moderato & Agak cepat (108-120 hitungan/ menit) \\
\hline Allegreto & Agak cepat (120-168 hitungan/ menit) \\
\hline Allegro & Cepat \\
\hline Presto & $\begin{array}{l}\text { Cepat sekali (168-200 hitungan/ } \\
\text { menit) }\end{array}$ \\
\hline Rit (Ritardando) & $\begin{array}{l}\text { Kecepatan sedikit demi sedikit } \\
\text { diperlambat }\end{array}$ \\
\hline $\begin{array}{l}\text { Rall } \\
\text { (Rallentando) }\end{array}$ & \begin{tabular}{l} 
Sama dengan Ritardando \\
\hline $\begin{array}{l}\text { Accel } \\
\text { (Accelerando) }\end{array}$
\end{tabular} \\
\hline Fermata & $\begin{array}{l}\text { Kecepatan sedikit demi sedikit } \\
\text { dipercepat }\end{array}$ \\
\hline fine & Hitungan ditahan beberapa saat \\
\hline Da capo (D.C) & Diulang dari awal \\
\hline Dal Segno (D.S) & Diulang dari tanda \& \\
\hline
\end{tabular}

\section{RITME}

Ritme adalah rangkaian gerak yang beraturan dan menjadi unsur dasar dari musik. Irama terbentuk dari sekelompok bunyi dan 
diam, panjang pendeknya dalam waktu yang bermacam-macam, membentuk pola irama dan bergerak menurut pulsa dalam setiap ayunan birama (Jamalus, 1998: 7). Pulsa adalah rangkaian denyutan yang terjadi berulang-ulang dan berlangsung secara teratur, dapat bergerak cepat maupun lambat ( ibid, 1998: 9). Ritme adalah pola gerakan/hitungan yang sama dan diulang terus menerus. Ritme atau Rhythmus adalah prinsip yang mengatur gerak lambar / cepat, waktu yang panjang / pendek. Ritme termasuk istilah dasar musik di samping melodi dan harmoni. Ritme adalah suatu istilah normative atau dinamis. Sejak abad V SM istilah ritme dikaitkan dengan gerak badan manusia yang teratur dalam tarian serta dalam musik instrumental. Platon mendefinisikan ritme sebagai "prinsip unsur gerak", khususnya gerakan badaniah. Artinya istilah ini tidak menyatakan apa adanya (misalnya panjang / pendeknya suatu bunyi) tetapi apa yang hendaknya ada (variasi dalam bunyi panjang dan pendek) ${ }^{2}$.

Pada abad XVI-XVII, musik menemukan kembali irama bahasa dan metrik. Maka berkembanglah ruang birama sebagai kesatuan musik dengan isi jumlah hitungan tertentu, dengan aksen berat dan ringan. Sekaligus berkembanglah gaya ritmis baru: irama bebas/resitatif, pergantian irama cepat dan lambat yang berasal dari instrumental. Hasilnya ialah jenis-jenis birama serta perbedaan tempo (Largo ... Vivace) sebagaimana kita kenal sampai sekarang.

Pada abad XVIII-XIX ritme menjadi kategori terpenting dalam musik klasik. Sebuah periode 8 birama secara lahiriah terdiri dari 2+2 birama untuk kalimat pertanyaan dan $2+2$ untuk kalimat jawaban.

${ }^{2}$ Karl-Edmund, Kamus Musik. 185 


\section{DINAMIKA (Dynamic)}

Dinamik adalah keras lembutnya dalam cara memainkan musik, dinyatakan dengan berbagai istilah seperti : $p$ (piano), $f$ (forte), mp (mezzopiano), mf (mezzoforte), cresc (crescendo), dan sebagainya (Banoe, 2003: 116). Dinamika adalah istilah yang digunakan untuk membedakan keras-lembutnya dalam pembawaan karya musik yang berfungsi untuk menyampaikan pesan emosi lagu.

Tanda dinamika berfungsi untuk menyatakan kuat (keras) atau lemah (lembut) sebuah lagu atau musik. Berikut beberapa contoh simbol tanda dinamika:

\section{Tanda Dinamika Berdasarkan Tingkat Kelembutan} Suara :

\begin{tabular}{|l|l|}
\hline$p$ (piano) & Lembut \\
\hline$p p$ (pianissimo) & Sangat lembut \\
\hline$p p p$ (pianississimo) $\quad$ (pianississimo & Selembut-lembutnya \\
\hline $\begin{array}{l}p p p p p \quad \text { Lebih lembut dari } p p p \\
\text { possibile) }\end{array}$ & \\
\hline$m p$ (mezzo piano) & Sedang lembutnya \\
\hline (decressendo) & Semakin lembut \\
\hline
\end{tabular}

2. Tanda Dinamika Berdasarkan Tingkat Kekerasan Suara :

\begin{tabular}{|l|l|}
\hline$f$ (forte) & Keras \\
\hline$f f$ (fortissimo) & Sangat keras \\
\hline$f f f$ (fortississimo) & Sekeras-kerasnya \\
\hline$f f f f$ (fortississimo possibile) & Lebih keras dari $f f f$ \\
\hline$m f$ (mezzo forte) & Sedang kerasnya \\
\hline & Semakin keras \\
\hline
\end{tabular}




\section{E. PITCH}

Pitch adalah ketepatan nada. Pitch berhubungan dengan frekwensi. Semakin rendah suara maka gelombang yang dihasilkan semakin lebar, dan semakin tinggi suara maka gelombang yang dihasilkan semakin rapat.

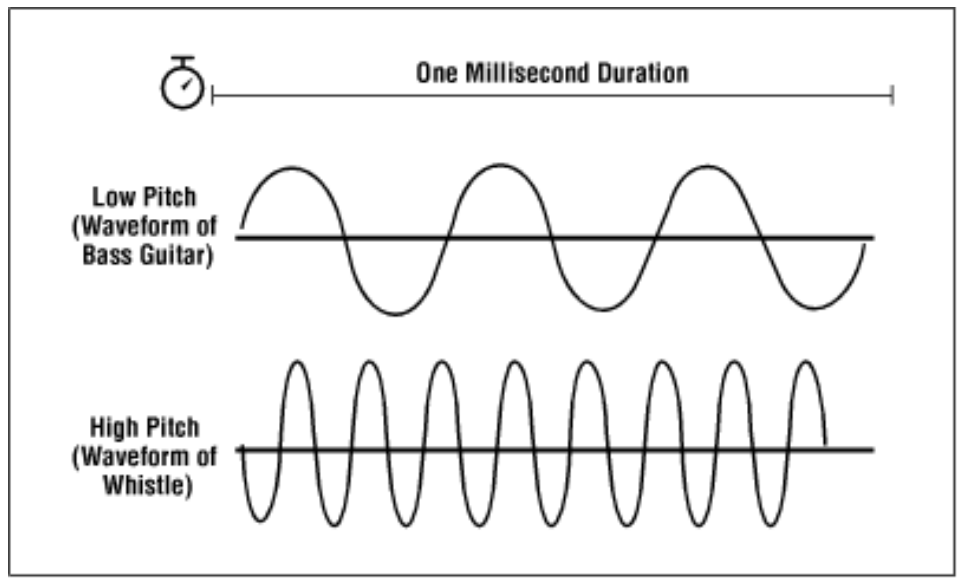

\section{F. TIMBRE}

Timbre adalah warna suara. Warna yang dimaksud adalah karakter suara yang dimiliki oleh tiap-tiap instrument, termasuk juga suara manusia. Tiap- tiap instrument memiliki karakter berbeda yang menghasilkan nuansa yang berbeda pula, dan hal ini yang disebut dengan Timbre. 


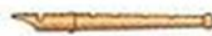

Flute

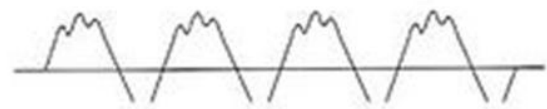

Voice

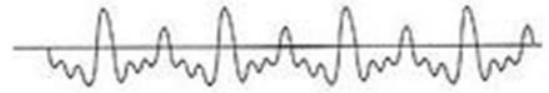

Violin

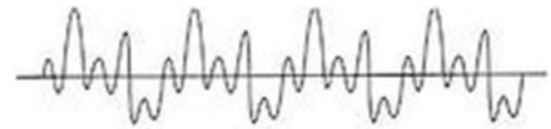

Didalam musik, selain unsur-unsur musik yang terdiri melodi, ritme, harmoni, dan dinamik, terdapat bentuk musik yang terdiri dari beberapa komponen, antara lain :

\section{1). Motif}

Motif adalah bagian terkecil dari suatu kalimat lagu, baik berupa kata, suku kata atau anak kalimat yang dapat dikembangkan (Banoe,2003 : 283)

\section{2). Tema}

Tema merupakan i-ide pokok yang mempunyai unsur-unsur musikal utama pada sebuah komposisi yang masih harus dikembangkan lagi, sehingga terbentuknya sebuah komposisi secara utuh. Dalam sebuah karya bisa mempunyai lebih dari satu tema pokok dimana masing-masing akan mengalami pengembangan. 


\section{3). Frase}

Frase adalah satu kesatuan unit yang secara konvensional terdiri dari 4 birama panjangnya dan ditandai dengan sebuah kadens. (Wicaksono : 1998). Frase dibagi menjadi 2 yaitu:

\section{a). Frase anteseden}

Adalah frase tanya atau frase depan dalam suatu kalimat lagu yang merupakan suatu pembuka kalimat, dan biasanya diakhiri dalam kadens setengah (pada umumnya jatuh pada akord dominan).

b). Frase konsekuen

Adalah frase jawab atau frase belakang dalam suatu kalimat dalam lagu dan pada umumnya jatuh pada akord tonika.

4). Kadens

Merupakan sejenis fungtuasi dan untuk mencapai efeknya menggunakan rangkaian akord-akord tertentu pada tempat tertentu dalam struktur musik. Terdapat beberapa macam kadens antara lain :
a). Kadens Authentic : progresi akord V - I
b). Kadens Plagal : progresi akord IV - I
c). Deceptif Kadens : progresi akord V - VI
d). Kadens Setengah : progresi akord I-V-I-IV

5). Periode atau Kalimat

Periode adalah gabungan dua frase atau lebih dalam sebuah wujud yang bersambung sehingga bersama-sama membentuk sebuah unit seksional ( Miller : 166). Kalimat musik merupakan suatu kesatuan yang nampak, antara lain pada akhir kalimat: disitu timbul kesan 'selesailah sesuatu', karena disini melodi masuk dalam salah satu nada akor tonika, namun lagunya 
dapat juga bermodulasi ke akor lain misalnya ke dominan dan berhenti di situ (Prier, 2004: 19) 
BIRAMA DAN MENDIREKSI

\section{A. BIRAMA / SUKAT}

Tanda birama / sukat merupakan bagian yang penting dalam sebuah komposisi lagu. Dengan tanda birama pemusik atau penyanyi tahu beat yang harus dinyanyikan, begitu pula untuk dirigen dan conductor, dengan melihat tanda birama menjadi tahu berapa hitungan dari beat yang harus dimainkan.

Sejak abad ke-17 kesatuan hitungan disebut beat/ Takt (dari kata Latin "tactus") dan ditulis dengan nada $1 / 4$. Dengan demikian nada panjang dan pendek dapat diatur dan dibandingkan. Pun pula beberapa hitungan dapat digabungkan dalam ruas birama; misalnya 4/4 atau "utuh" yang sejak awal abad ke-19 dipandang sebagai pola standar musik barat dengan pola aksen berat - ringan - sedang - ringan, diapiti dengan garis birama dengan definisi bahwa nada pertama sesudah garis birama merupakan nada berat/ beraksen (Karl-Edmund).

\section{Fungsi Birama}

Birama / sukat merupakan tanda yang berupa angka pecahan yang fungsinya untuk menentukan jumlah ketukan dan nilai tiap ketukan dalam satu birama. Di mana angka pembilang menunjukkan jumlah ketukan dalam satu birama, dan angka penyebut menunjukkan nilai dari tiap ketukan dalam satu birama. Seorang Dirigent dan Konduktor harus terlebih dahulu mengetahui berapa biramanya dan dimulai pada ketukan ke berapa lagu yang akan dimainkan. 


\section{Macam-Macam Tanda Birama}

Ada bermacam-macam tanda birama yang digunakan dalam musik, namun tanda birama yang pada umumnya digunakan adalah 4/4, 3/4, 2/3 dan 6/8

a. Tanda Birama 4/4. Dalam 1 birama terdapat 4 ketukan, tiap ketukan nilainya $1 / 4$. Ketukan berat terdapat pada ketukan 1 dan 3. Birama 4/4 banyak digunakan dalam lagu nasional, lagu daerah, bahkan lagu popular. Beberapa lagu yang menggunakan birama 4/4 antara lain lagu kebangsaan Indonesia Raya, Rayuan Pulau Kelapa, Syukur, Anak Gembala, Pemandangan, dan masih banyak lagi.

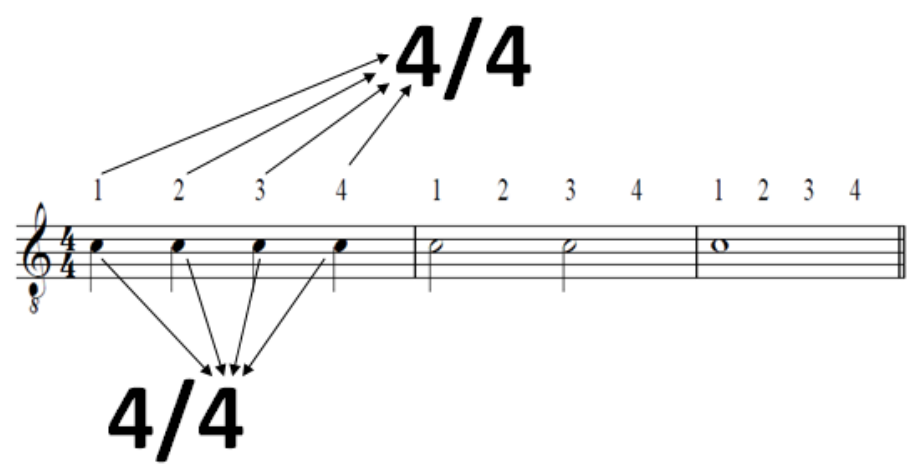

(Gambar: Notasi dalam tanda birama 4/4)

b. Tanda Birama $3 / 4$. Dalam 1 birama terdapat 3 ketukan, tiap ketukan nilainya $1 / 4$. Ketukan terberatnya jatuh pada ketukan pertama (1). Lagu-lagu yang menggunakan birama $3 / 4$ antara lain: Burung Kakak Tua, Alam Terhampar, Edelweiss dan sebagainya. 


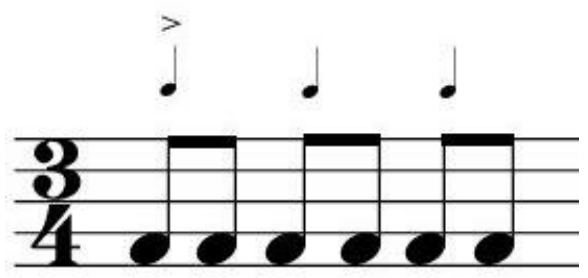

(Gambar: Notasi dalam birama 3/4)

c. Tanda Birama 2/4. Dalam 1 birama terdapat 2 ketukan, tiap ketukan nilainya $1 / 4$. Ketukan terberatnya ada pada ketukan pertama (1). Lagu-lagu dengan birama 2/4 biasanya berirama March dengan tempo cepat. Lagu-lagu dengan birama 2/4 antara lain: Hari Merdeka, Aku Seorang Kapiten, Halo-Halo Bandung, Maju Tak Gentar, dan lain sebagainya.

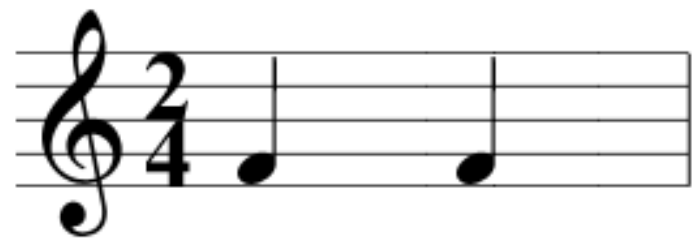

(Gambar : Notasi dalam tanda birama 2/4)

d. Tanda Birama 6/8. Dalam 1 birama terdapat 6 ketukan, tiap ketukan nilainya 1/8. Ketukan terberatnya terletak pada ketukan 1 dan 4 . Lagu dengan birama $6 / 3$ memiliki pola irama yang hampir sama dengan lagu dengan birama $3 / 4$. Lagu dengan birama 6/8 adalah lagu Desaku. 


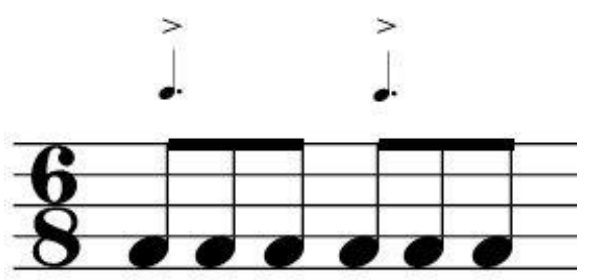

(Gambar: Notasi dalam birama 6/8)

\section{B. MENDIREKSI}

Mendireksi adalah kegiatan memberikan arahan atau abaaba kepada kelompok penyanyi, pemusik atau gabungan keduanya. Orang yang bertugas mendireksi disebut dengan Dirigen atau Konduktor (conductor). Terdapat beberapa jenis arahan atau abaaba di dalam musik, di mana arahan tersebut berhubungan dengan tanda birama yang digunakan dalam lagu yang akan dimainkan. Aba-aba 2 pukulan untuk lagu dengan birama 2/4, aba-aba 3 pukulan untuk lagu dengan birama $3 / 4$, aba-aba 4 pukulan untuk lagu dengan birama 4/4, dan aba-aba 6 pukulan untuk lagu dengan birama $6 / 8$.

\section{Fungsi dan Tujuan Kegiatan Mendireksi}

Seorang Dirigen atau Konduktor memiliki peran yang sangat penting, bukan hanya untuk menunjukkan ketukan atas lagu yang sedang dimainkan, namun juga berfungsi untuk memberikan arahan pada dinamika, tempo dan juga ekspresi yang harus dibawakan. Tujuannya adalah agar semua penyanyi atau pemusik menyanyikan/ memainkan lagu dengan tempo, dinamika dan ekspresi yang sama secara bersama-sama sehingga interpretasi lagu dapat dirasakan oleh pendengar. 


\section{Gerakan Mendireksi}

Dalam kegiatan mendireksi, setiap gerakan merupakan perwakilan dari tiap pukulan yang akan menentukan tempo dari lagu yang akan dimainkan

a. Gerakan Mendireksi 2 Ketukan

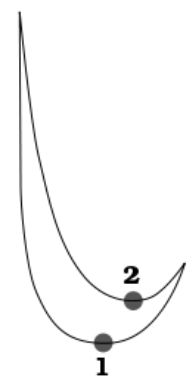

b. Gerakan Mendireksi 3 Ketukan

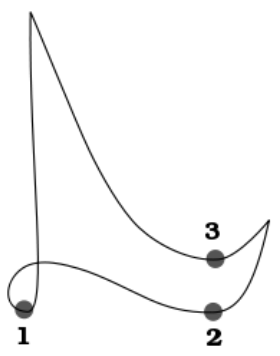




\section{c. Gerakan Mendireksi 4 Ketukan}

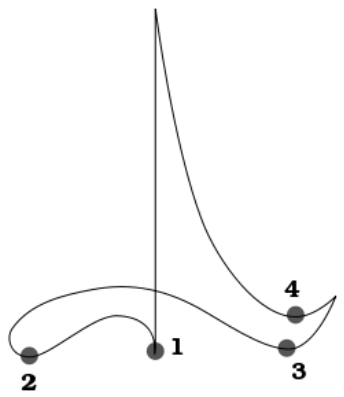

\section{d. Gerakan Mendireksi 6 Ketukan}
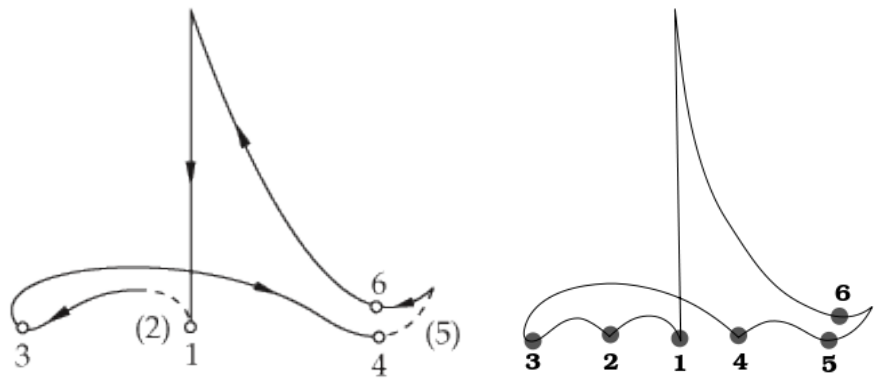

Dari beberapa gerakan direksi di atas dapat dilihat bahwa gerakan tangan untuk hitungan pertama/ satu dapat ditandai saat gerakan tangan dirigen lurus turun kebawah. Gerakan-gerakan tersebut dapat dilakukan dengan 2 tangan (kanan-kiri), atau dengan 2 tangan namun beda fungsi (tangan kanan menunjukkan ketukan atau pukulan, tangan kiri untuk menunjukkan dinamika dan ekspresi). 
NOTASI MUSIK

Musik adalah suatu susunan tinggi-rendah nada yang berjalan dalam waktu. Hal ini dapat dilihat dari notasi musik yang menggambarkan besarnya waktu dalam arah horisontal ( $\Rightarrow$ ), dan tinggi-rendah nada dalam arah vertikal ( 1 ). Ritme ditentukan oleh panjang atau lama waktu dari suatu bunyi. Panjang pendeknya bunyi digambarkan dengan simbol-simbol yang disebut dengan not (pitch), dan panjang pendeknya diam juga digambarkan dengan simbol-simbol yang disebut dengan tanda istirahat (rest).

Dalam dunia musik, dikenal berbagai jenis partitur, di antaranya seperti yang kita ketahui adalah notasi angka dan notasi balok. Namun sejak beberapa tahun terakhir sudah mulai dikenal notasi musik dalam bentuk yang baru, misalnya notasi grafik yang banyak digunakan dalam penulisan komposisi kontemporer. Perkembangan musik yang semakin pesat, menjadikan perkembangan yang terjadi bukan hanya di dalam komposisi, alat, tehnologi, industri maupun seniman kreatif saja, namun sampai pada tahapan transkrip sudah sampai pada cara yang baru.

\section{A. NOTASI ANGKA}

Notasi angka merupakan salah satu jenis notasi musik yang menggunakan lambang angka sebagai penunjuk tinggi rendahnya nada. Selain angka, terdapat juga titik di bawah maupun di atas angka yang menunjukkan tinggi rendahnya nada. Notasi angka tanpa menggunakan titik menunjukkan nada sedang, notasi dengan satu atau lebih titik di bawah not menunnjukkan nada rendah, dan notasi dengan satu atau lebih titik di atas not menunjukkan nada tinggi. 


\section{$\begin{array}{llllllllllllllllllllll}1 & 2 & 3 & 4 & 5 & 6 & 7 & 1 & 2 & 3 & 4 & 5 & 6 & 7 & 1 & 2 & 3 & 4 & 5 & 6 & 7 & 1\end{array}$}

\section{Harga, Nilai Not Dan Tanda Istirahat}

Dalam notasi angka, panjang pendeknya not saat dinyanyikan dan simbol ritmik atau durasi nilai dalam not digambarkan dengan menggunakan simbol yang berupa tanda garis di atas not atau titik di belakang not. Titik di belakang not berfungsi untuk menambahkan ketukan atau menambahkan durasi ketukan. Titik di belakang not memiliki harga yang sama seperti not angka.

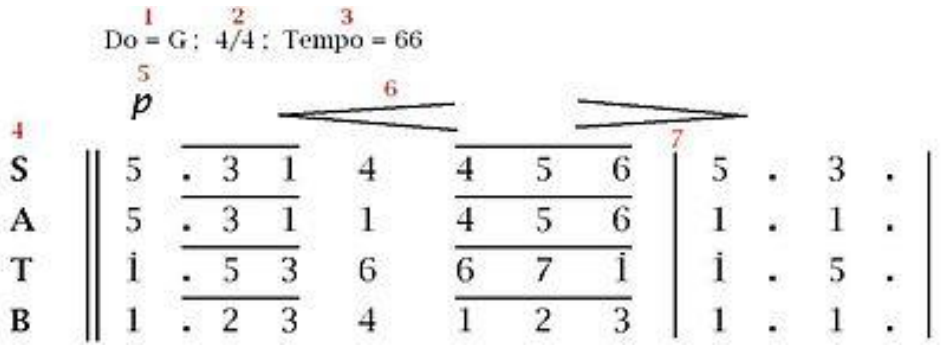

\section{Tanda Kromatis}

Dalam notasi angka, nada yang dinaikkan atau diturunkan mendapat tanda kromatis yang melekat pada not tersebut, dan tanda kromatis hanya berlaku untuk nada yang diberi tanda kromatis saja. Tanda kromatis dalam notasi angka ada 2 , yaitu:

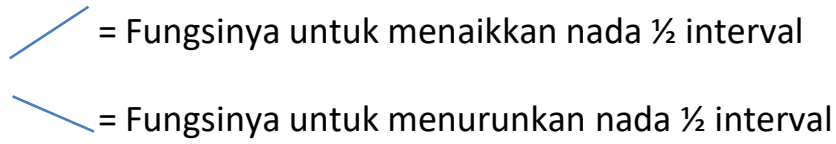




$$
\begin{aligned}
& \text { Do - Re - Mi - Fa - So - La - Si - Do } \\
& 1-2-3-4-5-6-7-1 \\
& 12 \quad 4 \quad 5 \quad 6 \\
& \begin{array}{lllll}
\text { Di } & \text { Ri } & \text { Fi } & \text { Sel } & \text { le }
\end{array}
\end{aligned}
$$

Contoh penulisan notasi lagu pada notasi angka:

\section{Indonerin Pusakn}

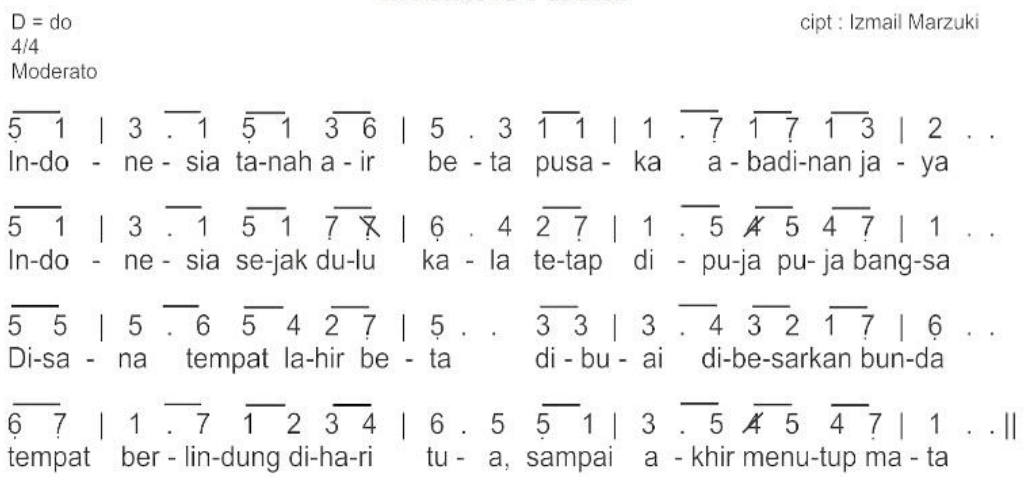

\section{B. NOTASI BALOK}

Notasi balok merupakan salah satu jenis notasi musik yang menggunakan symbol dalam penentuan nilai, harga, tanda diam dan tinggi rendahnya. Penentuan harga nada, nilai dan tanda diam dituliskan secara horizontal, dan untuk penentuan tinggi rendahnya nada dituliskan secara vertical.

\section{Nilai, Harga Not Dan Tanda Istirahat}

Dalam notasi balok, setiap nilai, harga dan tanda istirahat memiliki simbolnya masing-masing. Maka dari symbol tersebut kita dapat mengetahui berapa panjang 
ketukan, harga tiap ketukan dan berapa lama kesempatan untuk istirahat/ berhenti.

\begin{tabular}{|c|c|c|c|}
\hline Nama Not & Bentuk Not & Tanda Istirahat & Nilai \\
\hline Not Penuh & $\mathbf{0}$ & & 4 Ketuk \\
\hline Not $1 / 2$ & & & 2 Ketuk \\
\hline Not $1 / 4$ & & & 1 Ketuk \\
\hline Not $1 / 8$ & & & $1 / 2$ Ketuk \\
\hline Not $1 / 16$ & & & $1 / 4$ Ketuk \\
\hline Not $1 / 32$ & & & 1/8 Ketuk \\
\hline
\end{tabular}

\section{Not Bertitik dan Tanda Istirahat Bertitik}

Titik dalam notasi angka dan notasi balok memiliki fungsi yang berbeda. Jika di dalam notasi angka titik (.) memiliki nilai yang sama dengan not, maka dalam notasi balok memiliki aturan yang berbeda. Titik (.) dibelakang not berfungsi untuk menambahkan ketukan sebanyak setengah dari harga not yang ada di depannya.

\begin{tabular}{|c|c|c|l|}
\hline No. & Bentuk & Harga & \multicolumn{1}{|c|}{ Nilai Ketukan } \\
\hline 1. & 0. & $1 / 1+1 / 2$ & $4+2=6$ ketukan \\
2. & J. & $1 / 2+1 / 4$ & $2+1=3$ ketukan \\
3. & -. & $1 / 4+1 / 8$ & $1+1 / 2=11 / 2$ ketukan \\
4. & - & $1 / 8+1 / 16$ & $1 / 2+1 / 4=3 / 4$ ketukan \\
\hline
\end{tabular}




\section{Garis Paranada}

Sebelum kita mulai menuliskan not, terlebih dahulu kita harus membuat garis paranada untuk meletakkan notnot tersebut. Garis Paranada adalah tanda yang berupa 5 garis mendatar yang berfungsi untuk meletakkan not, tanda kunci, tanda kromatis, dan sebagainya dalam penulisan notasi balok

\section{Paranada}

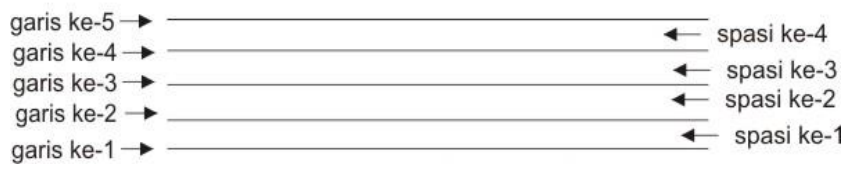

\section{Tanda Kunci}

Dalam penulisan notasi balok, sebelum kita menuliskan not-not terlebih daluhu kita meletakkan tanda kunci di awal paranada. Tanda kunci berfungsi untuk menentukan letak nada yang akan kita tuliskan. Tanpa tanda kunci, not balok tidak akan memiliki nada, hanya berupa ritmis saja. Dalam materi ini, kita akan pelajari 2 tanda kunci.

\section{a. Tanda Kunci G}

Tanda kunci $\mathrm{G}$ berfungsi untuk menuliskan nada-nada yang sedang sampai yang tinggi. Tanda kunci $G$ menunjukkan letak nada $\mathbf{G}$ pada garis ke-2 paranada. Notasi untuk vocal biasanya dituliskan dengan menggunakan tanda kunci $G$, kecuali notasi untuk suara Bass.

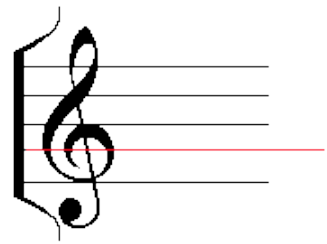




\section{Kunci G, menunjukkan letak not g' yaitu}

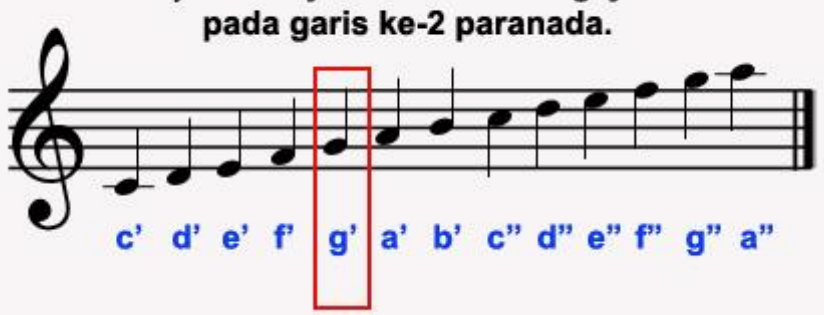

b. Tanda Kunci $\mathbf{F}$

Tanda kunci $\mathbf{F}$ berfungsi untuk menuliskan nada-nada yang rendah sampai yang sedang. Tanda kunci $\mathbf{F}$ menunjukkan nada F pada garis ke-4 paranada. Tanda kunci $\mathrm{F}$ digunakan untuk menuliskan notasi instrument yang memiliki nada rendah, atau pada notasi instrument piano, digunakan untuk menuliskan melodi untuk tangan kiri.

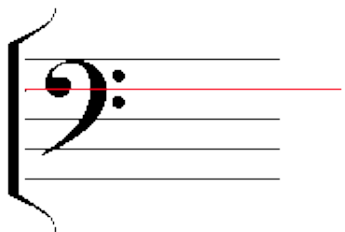

\section{Legato dan Legatura}

\section{a. Legato}

Legato adalah garis lengkung yang menghubungkan 2 nada atau lebih yang tidak sama. Nada-nada yang ada diberi tanda legato dinyanyikan dengan cara diayun.

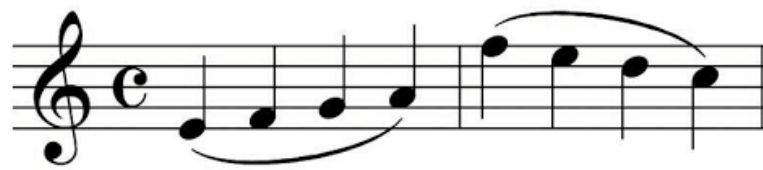




\section{b. Legatura}

Legatura adalah garis lengkung yang menghubungkan 2 nada yang sama. Legatura berfungsi untuk menambahkan atau memperpanjang ketukan sesuai dengan nilai atau harga nada yang ada di belakangnya. Nada kedua dalam legatura tidak dibaca, namun merupakan perpanjangan dari not yang ada di depannya.

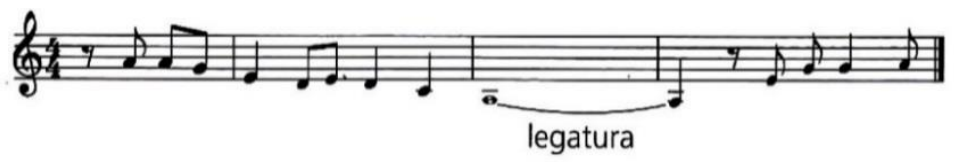

\section{Tanda Kromatis}

Tanda kromatis adalah tanda yang berfungsi untuk menaikkan dan menurunkan nada setengah interval lebih tinggi atau rendah, serta mengembalikan nada yang telah dinaikkan atau diturunkan kembali ke nada semula.

\section{a. Macam Tanda Kromatis}

1). Kres atau sharp ( $\$$ ) adalah tanda yang berfungsi untuk menaikkan nada setengah interval lebih tinggi. Nada yang di kres diberi akhiran "is".

Contoh: Nada C di kres menjadi Cis

2). Mol atauflat ( b) adalah tanda yang berfungsi untuk menurunkan nada setengah interval lebih rendah. Nada yang di mol diberi akhiran "es".

Contoh: Nada C di mol menjadi Ces

3). Pugar atau natural ( $b$ ) adalah tanda yang berfungsi untuk menetralkan kembali nada - nada 
yang di kres atau di mol untuk dikembalikan ke nada semula.

Contoh: Naca Cis di pugar kembali ke C

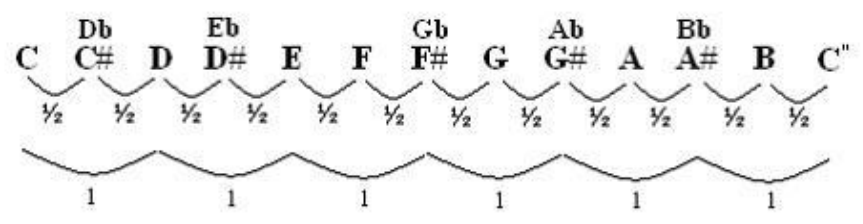

\section{Tangga Nada Kromatis}

Dalam notasi balok terdapat banyak tangga nada yang menggunakan tanda kromatis kres dan mol. Jadi, "Do" itu bukan hanya nada " $C$ ", melainkan semua nada dapat berperan sebagai tonika. Hal ini sangat penting untuk dipelajari karena suara manusia dan instrument musik memiliki ambitus yang terbatas, maka perlu nada dasar lain agar lagu lebih nyaman dalam dibawakan. Tangga nada kromatis dibagi menjadi 2, yaitu tangga nada dengan kres dan tangga nada dengan mol.

\section{a. Tangga Nada Kres}

Ada beberapa rumus yang digunakan dalam menentukan tangga nada dengan menggunakan kres, salah satunya adalah dengan berpatokan pada jarak interval tangga nada: $1-1-1 / 2-1-1-1-1 / 2$. Atau kita dapat juga menggunakan langkah sebagai berikut: Nada ke-5 dari TN sebelumnya sebagai Tonika (Do), nada ke-7 dinaikkan $1 / 2(\sharp)$. Silahkan tentukan rumus mana yang menurut anda lebih mudah dipahami. 
Tabel Tangga Nada Kromatis Kres ( $\sharp)$ :

\begin{tabular}{|c|c|c|c|c|c|c|c|c|}
\hline TN & $\mathrm{C}$ & $D$ & $E$ & $F$ & $\mathrm{G}$ & $A$ & $B$ & $\mathrm{C}$ \\
\hline $1 \#$ & $\mathrm{G}$ & A & B & $C$ & $D$ & $E$ & $F^{\#}$ & $\mathrm{G}$ \\
\hline $2 \#$ & $D$ & $E$ & $F^{\#}$ & G & $A$ & B & $C \#$ & $\mathrm{D}$ \\
\hline $3 \#$ & A & $B$ & $C \#$ & $D$ & $E$ & $\mathrm{~F}^{\sharp}$ & $\# G$ & $A$ \\
\hline $4 \#$ & $E$ & $\mathrm{~F} \#$ & $G^{\#}$ & $A$ & $B$ & $C \#$ & $D \#$ & $E$ \\
\hline $5 \#$ & $B$ & $C \#$ & $D H$ & $E$ & $\mathrm{~F} \#$ & $G^{\#}$ & $A \sharp$ & $B$ \\
\hline $6 \#$ & $F^{H}$ & $G \#$ & $A \#$ & B & $C \#$ & $\mathrm{DH}$ & E\# & $F^{\#}$ \\
\hline $7 \sharp$ & $C \#$ & $D^{\#}$ & $E^{\#}$ & $F^{\#}$ & $\mathrm{GH}^{\#}$ & $A \#$ & $B \#$ & $C^{H}$ \\
\hline
\end{tabular}

b. Tangga Nada Kromatis Mol

Penentuan tangga nada dengan tanda kromatis mol (b) tidak jauh berbeda dengan tangga nada kres. Penentuan tangga nada kromatis mol dapat ditentukan dengan melihat jarak interval antar nada: $1-1-1 / 2-1-1-1-1 / 2$, atau kita juga dapat menggunakan langkah sebagai berikut: Nada ke-4 dari TN sebelumnya sebagai Tonika, nada ke-4 diturunkan $1 / 2$ interval (di mol).

Tabel Tangga Nada Kromatis Mol (b):

\begin{tabular}{|c|c|c|c|c|c|c|c|c|}
\hline $\mathrm{TN}$ & $\mathrm{C}$ & $D$ & $E$ & $F$ & $G$ & $A$ & $B$ & $C$ \\
\hline $1 b$ & $\mathrm{~F}$ & G & $A$ & $B b$ & $C$ & $D$ & $E$ & $F$ \\
\hline $2 b$ & $\mathrm{~B} b$ & $C$ & $D$ & $E b$ & $\mathrm{~F}$ & G & $A$ & $\mathrm{~B} b$ \\
\hline $3 b$ & $E b$ & $F$ & G & $A b$ & $\mathrm{Bb}$ & C & D & $E b$ \\
\hline $4 b$ & $A b$ & $\mathrm{~B} b$ & $C$ & $\mathrm{Db}$ & $E b$ & $\mathrm{~F}$ & G & $A b$ \\
\hline $5 b$ & $\mathrm{Db}$ & $E b$ & $F$ & Gb & $A b$ & $\mathrm{Bb}$ & $C$ & $\mathrm{Db}$ \\
\hline $6 b$ & $\mathrm{~Gb}$ & $A b$ & $B b$ & $\mathrm{Cb}$ & $\mathrm{Db}$ & $\mathrm{Eb}$ & $F$ & $\mathrm{~Gb}$ \\
\hline $7 b$ & $c b$ & $\mathrm{Db}$ & $E b$ & $\mathrm{Fb}$ & $\mathrm{Gb}$ & $A b$ & $\mathrm{Bb}$ & $c b$ \\
\hline
\end{tabular}


Contoh penulisan lagu menggunakan notasi balok :

Do $=$ Bes

Satu Nusa Satu Bangsa

4/4, Andante maestoso
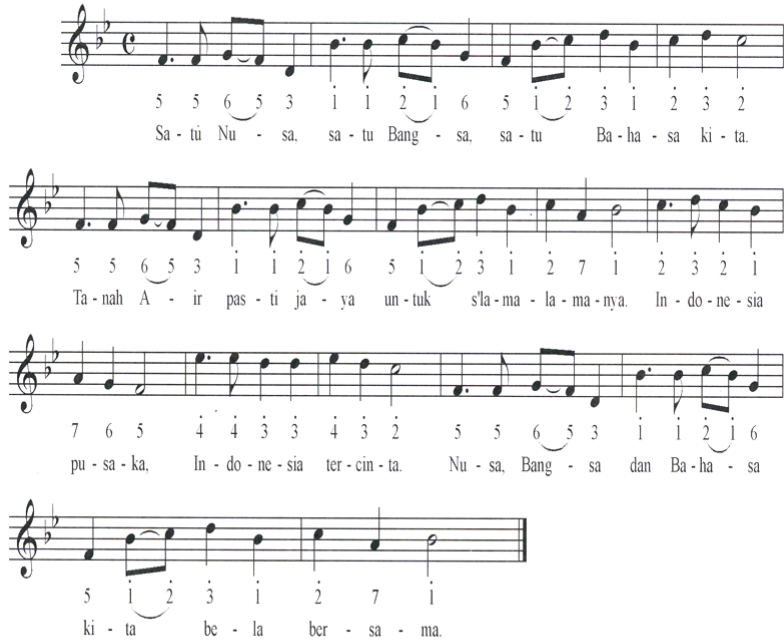


\section{BERNYANYI}

Bernyanyi merupakan kegiatan yang tak terpisahkan dalam proses belajar mengajar di TK/ PAUD. Hampir dalam setiap kegiatan bermain dan belajar selalu diselingi dengan kegiatan bernyanyi. Dan sudah seharusnya seorang guru PAUD menguasai tehnik bernyanyi dengan baik dan tahu poin-poin yang harus disampaikan sebelum mengajak anak didik bernyanyi.

Teknik bernyanyi untuk Anak Usia Dini harus diawali dengan cara yang menyenangkan, agar anak lebih tertarik dan lebih mudah menerima setiap materi yang diberikan. Hal yang paling mendasar dari bernyanyi adalah teknik pernafasan, ketepatan nada (pitch) dan sikap tubuh. Teknik pernafasan yang tepat dan sikap tubuh yang baik sangat dibutuhkan dalam proses produksi suara, agar nada-nada dapat dinyanyikan dengan lebih baik.

Dalam bernyanyi, baik untuk anak-anak, remaja, ataupun dewasa, ada beberapa hal yang perlu diperhatikan. Pertama, ajarkan tentang teknik pernafasan yang benar. Dari pernafasan dada, perut dan diafragma, manakah yang boleh digunakan. Lakukan cek pernafasan. Kedua, ajaklah siswa untuk melakukan vocalizing untuk latihan tuning nada dan mempersiapkan pita suara sebelum mulai bernyanyi. Ketiga, pilihlah lagu dengan tingkat kesulitan yang sesuai dengan kemampuan dengan nada dasar yang sesuai dengan range suara siswa. Dan tak lupa, pilihlah lagu yang sesuai dengan usia siswa. Yang sering terjadi adalah anak-anak menyanyikan lagu dengan tingkat kesulitan tinggi yang belum sesuai dengan kemampuannya, atau anak-anak menyanyikan lagu dengan tema yang lebih cocok dinyanyikan oleh orang dewasa. 
Namun sebelum mulai bernyanyi, kita pelajari dahulu unsur-unsur penting dalam bernyanyi.

\section{A. Pernafasan}

Organ-organ penting yang menyalurkan udara ke suara adalah paru-paru. Akan tetapi tidak banyak orang yang menggunakan paru-paru dengan efisien. Dipandang dari segi kepentingan penyaluran dan pemeliharaan udara bagi tubuh manusia, belajar menyanyi itu patut diperhatikan dan dipraktekkan. Sebelum dapat menyanyi dengan baik, harus lebih dahulu belajar menggunakan udara di bawah tenggorokan. Untuk itu dalam beberapa waktu yang lama harus melakukan latihan-latihan bernafas secara khusus. Sebagai langkah awal, seseorang yang akan menyanyi dapat berdiri dengan tegak di depan sebuah cermin, dimana ia dapat melihat seluruh tubuhnya sendiri. Setelah itu mengeluarkan nafas sebanyakbanyaknya, kemudian menarik napas dalam-dalam melalui hidung sehingga terasa betul-betul penuh. Setelah itu nafas ditahan selama beberapa detik, secara pelan-pelan semua udara dikeluarkan melalui mulut dengan meniupkan keluar.

Dalam bernyanyi, pernafasan tidak hanya memegang peranan dalam menciptakan suara, tetapi juga suara yang dikehendaki dari suatu nyanyian. Pernafasan yang teratur akan menciptakan irama yang teratur pula, karena bernafas merupakan irama yang sangat alamiah dalam kehidupan manusia.

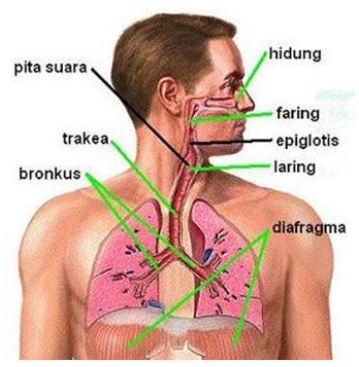


Jenis pernafasan yang dapat digunakan dalam bernyanyi adalah:

1. Pernapasan Diafragma; yaitu pernafasan yang dilakukan dengan cara mengambil nafas kemudian dimasukkan kedalam paru-paru sehingga terisi penuh tanpa terjepit. Ruangan akan leluasa dengan menegangnya sekat rongga badan atau diafragma yang bergerak kebawah.

2. Pernapasan Dada; yaitu pernafasan yang dilakukan dengan cara mengambil nafas sepenuhnya kemudian dimasukkan kedalam paru-paru sehingga rongga dada membusung ke depan. Kelemahan pernafasan ini adalah paru-paru cepat lelah dalam menahan udara, maka yang dihasilkan tidak stabil karena udara yang dikeluarkan kurang dapat diatur.

3. Pernapasan Bahu; yaitu pernafasan yang dilakukan dengan cara mengambil nafas dengan mengembangkan bagian atas paru-paru, sehingga mendesak bahu menjadi terangkat keatas. Kelemahan pernafasan ini adalah tidak dapat tahan lama dan sikap tubuh kurang enak untuk dilihat.

Dari ketiga jenis pernafasan diatas, pernafasan diafragmalah yang paling baik digunakan pada waktu bernyanyi. Tetapi tidak semua orang dapat melakukannya dengan mudah, harus melalui tahap-tahap latihan yang teratur. Biasanya, yang sering dilakukan dalam bernyanyi adalah diafragma tidak bergerak, paru-paru tidak diisi sepenuhnya dan nafasnya pendek-pendek. Oleh karena itu diafragma dan semua pergerakan otot-otot perut dan sisi badan harus dilatih untuk 
mengadakan ketegangan serta pengenduran yang sengaja dan disadari. Harus diperhatikan juga bahwa dasar untuk bernafas dengan baik adalah keseimbangan antara sikap bertegang dan sikap kendur. Untuk itu badan bersikap relaks, agar dapat menghirup udara dengan baik.

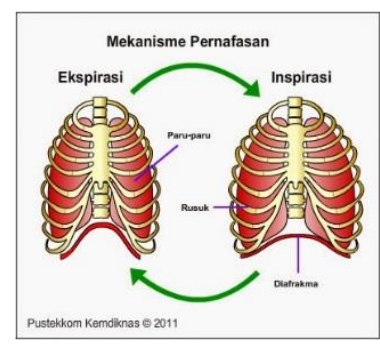

(Mekanisme Pernafasan Diafragma)

\section{B. Sikap Badan}

Untuk dapat tampil menyanyi dengan baik, diperlukan sikap tubuh yang rileks namun penuh tenaga. Tubuh yang rileks adalah sikap yang baik dan benar. Secara fisik, sikap bernyanyi adalah seluruh bagian tubuh harus selalu dalam keadaan tidak kaku. Menggerakkan kaki, tangan, kepala dan badan seperlunya. Secara psikispun, dalam menyanyi perlu jiwa yang lentur atau tidak tegang. Pikiran harus positif dan jiwa perlu dilarutkan pada gerak musik. Apabila fisik dan jiwa sudah lentur, harus disiapkan mental yang akan mendukung vokal yang enak. Cara menumbuhkan sikap mental yang relax dan powerfull, selain memperhatikan faktor di atas juga meningkatkan jam terbang seefektif mungkin. Sikap tubuh waktu menyanyi merupakan hal yang penting. 


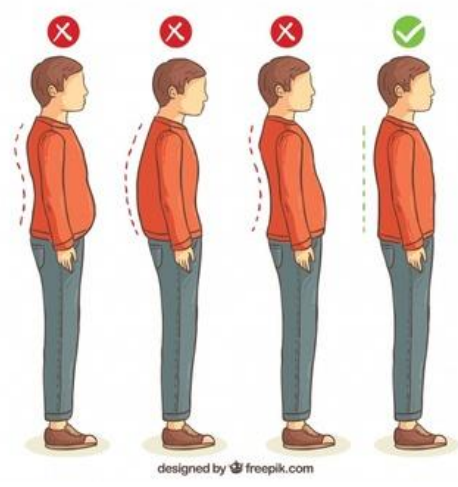

Untuk menjaga agar tidak menimbulkan ketegangan, maka berlatih untuk tidak selalu mengangkat bahu dan tidak menggerakkan dada keatas harus dikuasai oleh seorang penyanyi. Biasanya, ketegangan-ketegangan yang terjadi diakibatkan oleh keadaan jasmaniah maupun rohaniah (psikis). Keadaan jasmaniah yang sakit atau lelah mempengaruhi pernafasan. Nafas menjadi pendek dan gelisah. Keadaan rohaniah yang dapat menimbulkan ketegangan yaitu ketakutan, cemas, demam panggung dan sebagainya.

Dalam ketegangan yang tidak wajar, semua nyanyian yang sudah dilatih dengan baik dapat hilang seketika atau gagal. Untuk itu sikap menyanyi yang baik adalah dengan sikap bebas dari semua ketegangan, konsentrasi untuk menyanyi dan harus pandai menguasai diri. Sikap tubuh yang lain adalah tidak kaku, tidak membungkuk tetapi jangan terlalu menengadah keatas. Posisi kaki kanan agak maju, supaya berat badan dapat berpindah-pindah dengan relaks.

\section{Artikulasi}

Bentuk atau sikap mulut sewaktu menyanyi sangat mempengaruhi pembentukan nada yang dihasilkan. Kesalahan umum yang terjadi pada awal pelajaran menyanyi adalah bahwa 
mereka tidak bisa membuka mulutnya, sehingga suara yang dihasilkan kurang jelas. Banyak yang dihinggapi rasa rendah diri, malu jika ditertawakan apabila membuka mulutnya terlalu lebar. Padahal dalam menyanyi tidak usah terlalu memikirkan bagaimana bentuk wajah atau mulut, asalkan bernyanyi dengan sewajarnya dan tidak dibuat-buat. Diksi dan artikulasi yang baik tergantung dari cara membuka mulut masing-masing penyanyi. Kadang-kadang sebelum belajar menyanyi terlebih dahulu harus belajar berbicara.

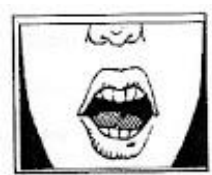

$\mathrm{AH}(\mathrm{a})$

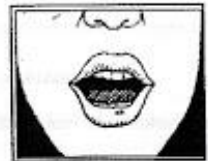

$\mathrm{AE}(\mathrm{e})$

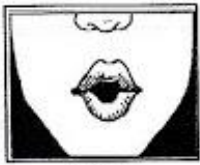

OO(u)

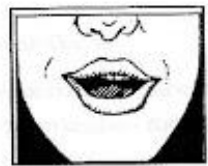

EE (i)

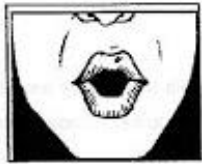

$\mathrm{OH}(0)$

\section{Resonansi}

Resonansi adalah fenomena yang ada sangkut pautnya dengan banyaknya rongga dalam tubuh manusia. Setiap orang yang menyanyi, resonansi akan timbul dari suara yang dihasilkan. Oleh sebab itu resonansi membantu memperbesar luas suara dan memperkuat daya tahan suara. Ruang resonansi utama terdapat di dalam kepala, dengan banyak bilik udara yang besar atau kecil, dan berpengaruh terhadap pembentukan suara. 


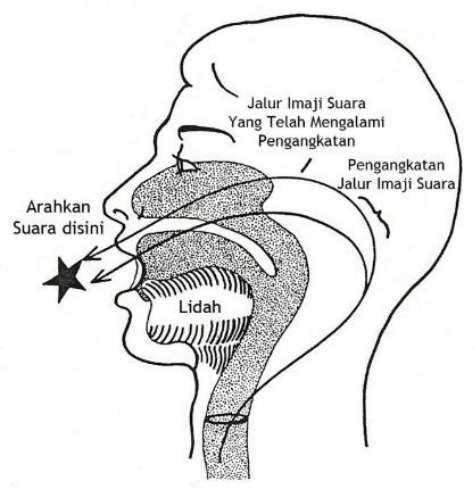

\section{E. Phrasering}

Phrasering adalah aturan pemenggalan kalimat yang baik dan benar sehingga mudah dimengerti dan sesuai dengan kaidah-kaidah yang berlaku. Dengan kata lain, Phrasering adalah pemenggalan kalimat musik menjadi bagian-bagian yang lebih pendek, tetapi tetap mempunyai kesatuan arti. Tujuan phrasering adalah agar dapat memenggal kalimat musik lebih tepat sesuai dengan isi kalimat. Dengan demikian usaha untuk mengungkapkan suatu lagu dapat lebih mendekati kebenaran yang terkandung di dalamnya sesuai dengan pesan lagu tersebut.

\section{F. Ekspresi/ Penghayatan}

Seorang penyanyi harus dapat membawakan lagu dengan baik dari suatu ciptaan sesuai dengan jiwa lagu tersebut, misalnya sedih, gembira, semangat dan sebagainya. Sebuah lagu yang gembira harus pula disertai dengan mimik atau gerakan yang gembira pula. Bernyanyi dengan 'perasaan' berarti bernyanyi dengan 'hati'. Sebelum menyanyikan lagu, alangkah baiknya jika sudah menghayati apa yang akan dinyanyikan. Karena selama bernyanyi harus menghayati isi 
nyanyian dengan perasaan/hati. Banyak penyanyi memusatkan perhatian pada dirinya sendiri, bukan pada nyanyian yang sedang dibawakan. Tidak ada nyanyian ekspresif yang dilakukan sambil mengingat-ingat lagu yang dibawakan, apalagi bila sambil membaca syairnya. Oleh sebab itu sebelum tampil, hafalkan lirik lagu yang akan dibawakan. Setelah hafal lirik lagunya, pahami betul apa makna pesan yang ada pada lagu tersebut, kemudian pahami makna dan pesannya, pastikan apakah jiwa dasar lagu itu sedih, marah, semangat, gembira dan sebagainya. Setelah berhasil menjiwai syair lagu, nyanyikan melodi tersebut tanpa syair dengan tetap berintegrasi pada jiwa dasar penafsiran tentang syair.

Setelah syair lagu dikuasai, masih ada satu lagi yang harus dilalui yaitu faktor musik pengiring yang berguna fungsinya untuk membawa pada perasaan yang lebih mendalam. Saat menyanyi dengan iringan musik, satukan perasaan lagu dengan suasana musik pengiring. Kiat sederhana dalam menjiwai irama musik pengiring, yaitu berinteraksilah, terutama dengan salah satu instrument (apabila diiringi lebih dari satu instrument), karena instrument memiliki perasaan yang lebih menonjol terhadap irama. Ekspresi adalah penguasaan syair, lagu, sambil menjiwai atau menghayati secara keseluruhan. Untuk itu diperlukan beberapa teknik penjiwaan di dalam bernyanyi.

Teknik penjiwaan adalah cara untuk menguasai teknikteknik bernyanyi, yaitu merubah dinamika atau volume suara. Teknik penjiwaan yang biasa dilakukan adalah dinamika atau perubahan keras lembutnya suara sesuai dengan tanda-tanda atau perasaan. Tanda dinamik terletak dalam struktur kalimat musik yang pada umumnya terdiri dari dua bagian, yaitu bagian sebelum puncak yang disertai dengan crescendo dan bagian sesudah puncak yang disertai dengan decrescendo. Disamping merubah dinamika atau volume suara, memilih 
tempo yang tepat untuk sebuah nyanyian, juga penting sekali dalam penjiwaan. Karena semua istilah seperti allegro (cepat) moderato (sedang), lambat (andante) dan seterusnya sangat relatif, maka penyanyi harus mencoba tempo mana yang sesuai dengan nyanyian yang ia bawakan.

Dalam mengungkapkan nyanyian terlebih dahulu mempelajari penjiwaan. Mula-mula dengan memilih nyanyian yang memancing gerak-gerik; Kemudian menyanyikan lagulagu yang lebih serius. Tidak bernyanyi terlalu keras, dan jangan bernyanyi hanya dengan suara tetapi dengan wajah. Suara selalu dijiwai oleh penghayatan akan isi dan maksud nyanyian, dan oleh hati yang tidak pernah meninggalkan suara. Perlu juga membaca teks tidak hanya dengan mata tetapi dengan suara seolah-olah seperti baca puisi.

Di dalam teknik penjiwaan, menjiwai ornamen vokal juga sangat diperlukan. Ornamen artinya hiasan atau variasi. Khusus dalam vocal yang lazim dikatagorikan sebagai ornamen, yaitu improvisasi atau hiasan yang dilakukan secara mendadak dan impromptu atau hiasan yang direncanakan. Ornamentasi pada dasarnya bertujuan membuat lagu menjadi lebih hangat dan lebih kaya nuansa. Ornamentasi tidak akan bermakna apapun apabila dilakukan tidak dengan sepenuh jiwa. Mengingat menyanyi merupakan pekerjaan hati, maka prinsip dasar saat melakukan ornamen vokalpun tetap perlu dilakukan dengan penuh perasaan.

Yang termasuk dalam katagori ornamentasi vokal, selain memproduksi soft distorsi dan distorsi, termasuk vibrato, echo, tremolo, falsetto/kopstem. Distorsi adalah vokal suara yang dibuat dengan kesan kasar seperti penyanyi rock, sedangkan soft distorsi merupakan vokal yang lembut dan serak. Seperti suara Krisdayanti, Stevie Wonder, Celine Dion dan sebagainya. Teknik vibrato adalah gelombang vokal lembut yang mendalam, 
sebagaimana yang banyak dilakukan hampir semua penyanyi pop. Teknik tremolo adalah getaran vocal yang lebih rapat seperti yang banyak dilakukan para penyanyi seriosa. Teknik echo adalah cara bernyanyi mendesah, hal ini sering digunakan oleh para penyanyi yang kurang memiliki potensi mengalunkan gelombang vibrato atau tremolo. Kopstem/falsetto adalah suara palsu yang ditujukan bagi pria dan dapat dimanfaatkan sebagai ornamen. Pemanfaatan kopstem adalah untuk bagian nada yang masih bisa dijangkau dengan suara asli.

Bagi yang belum memahami banyak tentang harmoni, sebaiknya tidak menyajikan ornamentasi secara revolusional. Karena dapat terjebak pada ornamen yang tidak proporsional. Ornamentasi bukan kewajiban utama bagi seorang penyanyi, kewajiban utama adalah menyanyi dengan penuh perasaan. Dalam dunia nyanyi populer, penjiwaan diperlukan untuk menyajikan ornamentasi. Tidak ada ukuran yang jelas tentang ornamentasi selama dibawakan dengan hati.

Dinamik adalah bahasa musik yang mengandung makna keras lembutnya suara. Penyanyi seperti Rosa, Titik Puspa, Celine Dion, pandai menghanyutkan perasaan pendengarnya. Musik populer tergolong corak musik yang menuntut permainan dinamik yang variatif. Oleh sebab itu para penyanyi musik populer profesional pandai mengombang-ambingkan perasaan pendengarnya.

Komunikasi vokal yang tidak musikal adalah berbicara atau berkata-kata, sedangkan menyanyi adalah komunikasi vokal secara melodis. Seorang penyanyi dituntut selalu bisa menjiwai berbagai aspek perilakunya di panggung. Gerak tangannya, langkah kakinya, termasuk saat mengucapkan katakatapun perlu dijiwai. Dengan menjiwai gerakan alat-alat pengucapan, berarti telah menyajikan teknik diksi atau gaya 
pengucapan yang lebih menarik serta dapat bermanfaat untuk mempertegas karakter suara.

G. Vocalizing Dasar

1.

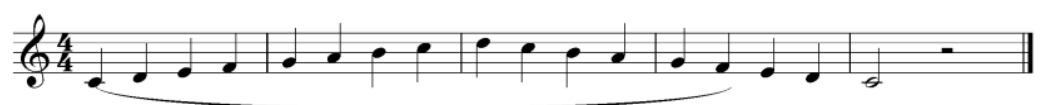

2.

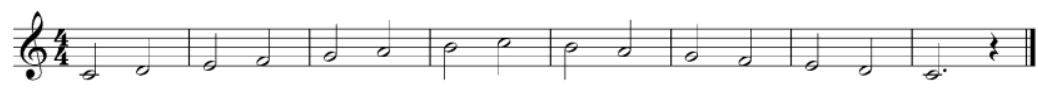

3.
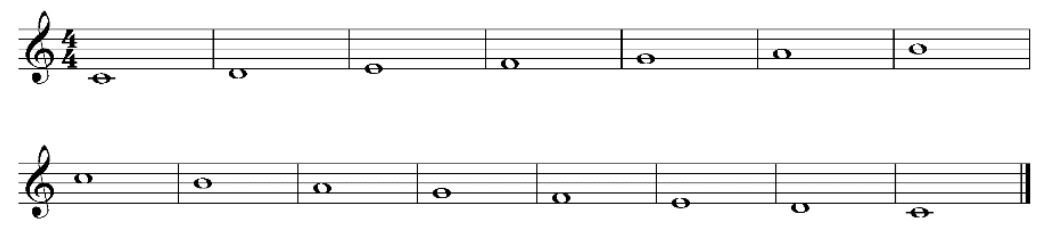

4.
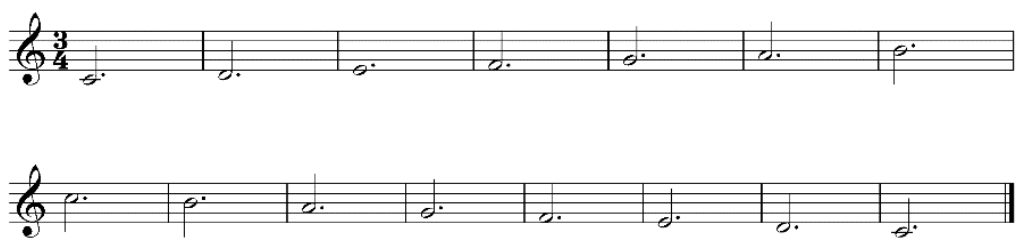


\section{KLASIFIKASI INSTRUMENT MUSIK}

Instrumen musik memiliki warna suara, fungsi dan sumber bunyi yang berbeda-beda, maka dari itu instrument musik diklasifikasikan berdasarkan fungsinya, cara memainkannya, dan sumber bunyinya.

\section{A. Klasifikasi Instrument Musik Berdasarkan Fungsinya}

Setiap instrument musik diciptakan dengan fungsi dan karakternya masing-masing, agar dapat menyatu dalam karya music dan keberadaannya memberikan warna tersendiri.

\section{Instrumen Musik Melodis}

Instrumen musik melodis adalah alat musik yang berfungsi memainkan melodis. Pada umumnya alat music ini tidak dapat memainkan akord secara tunggal. Yang termasuk dalam klasifikasi instrument melodis antara lain: biola, rekorder, saxophone, flute, dan sebagainya.
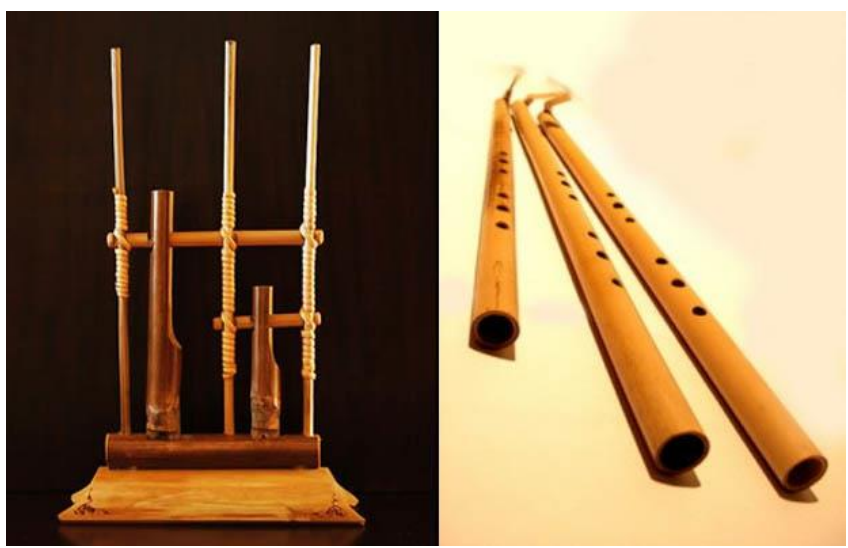


\section{Instrumen Musik Harmonis}

Instrumen musik harmonis adalah instrument yang berfungsi sebagai pengiring dan dapat memainkan akord secara tunggal. Yang termasuk dalam klasifikasi instrument harmonis adalah: piano, keyboard, akordeon, gitar, harpa, sitar, kecapi, dan sebagainya.

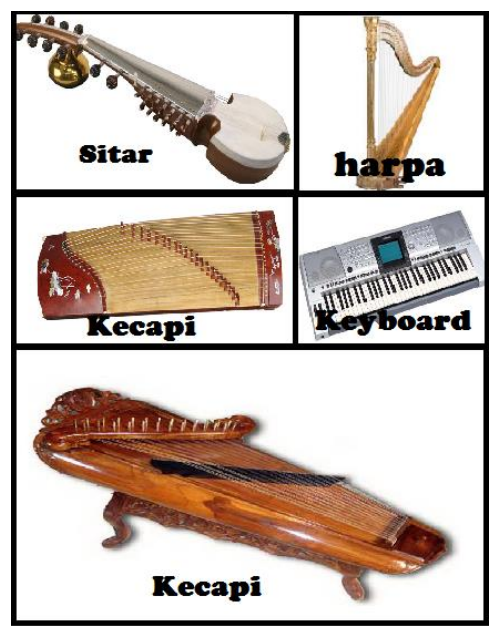

\section{Instrumen Musik Ritmis}

Instrument music ritmis adalah instrument yang fungsinya sebagai pengiring yang mengatur ritmis dan tempo dalam music. Yang termasuk dalam klasifikasi instrument ritmis adalah: drum, kendang, bongo, tamborin, kahoon, dan sebagainya.
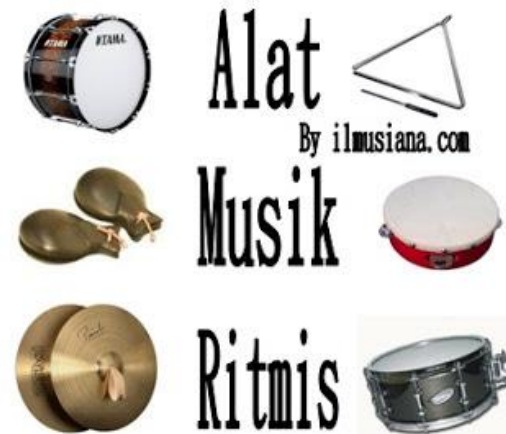


\section{B. Klasifikasi Instrument Musik Berdasarkan Sumber Bunyinya}

\section{Idiophone}

Instrumen idiophone adalah instrument music yang sumber bunyinya berasal dari badan atau bahan dasar instrument. Yang termasuk instrument idiophone adalah cymbal, triangle, kastanyet, angklung, bonang, saron, demung, marimba, kulintang, dan sebagainya.

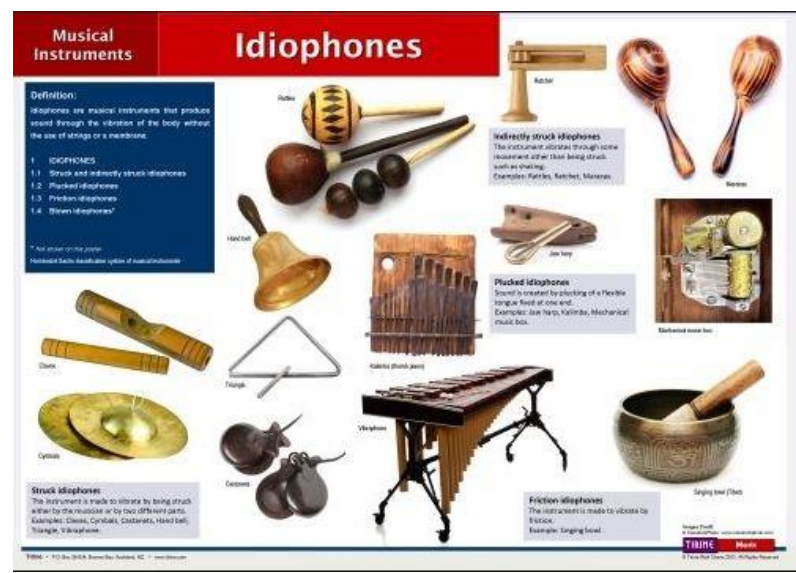

\section{Cordophone}

Instrumen cordophone adalah instrument music yang sumber bunyinya berasal dari dentingan dawai atau senar. Yang termasuk instrument cordophone adalah gitar, sitar, piano, kecapi, sasando, harpa, biola, rebab, cello, dan sebagainya. 


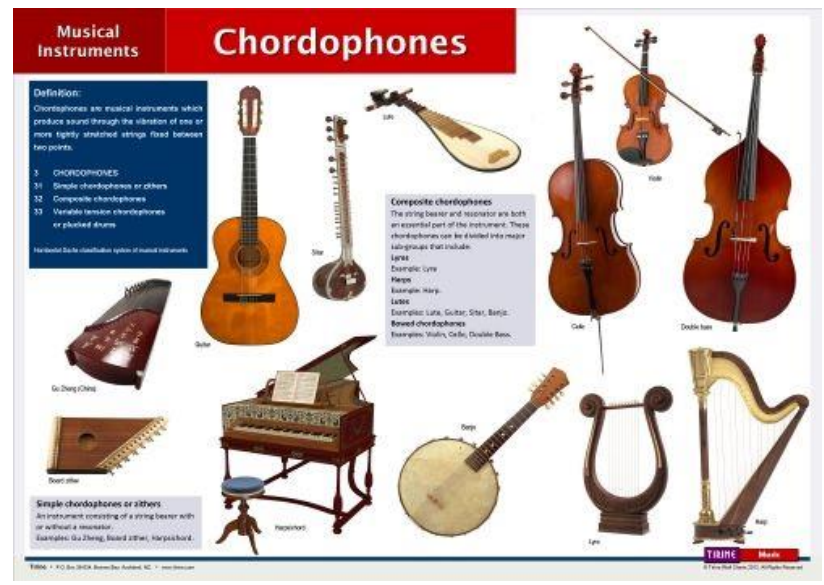

\section{Aerophone}

Instrumen aerophone adalah instrument music yang sumber bunyinya berasal dari getaran udara. Instrument ini umumnya dimainkan dengan cara ditiup. Yang termasuk instrument aerophone adalah recorder, flute, trombone, pianika, acordeon, trumpet, saxophone, horn, harmonica, dan sebagainya.

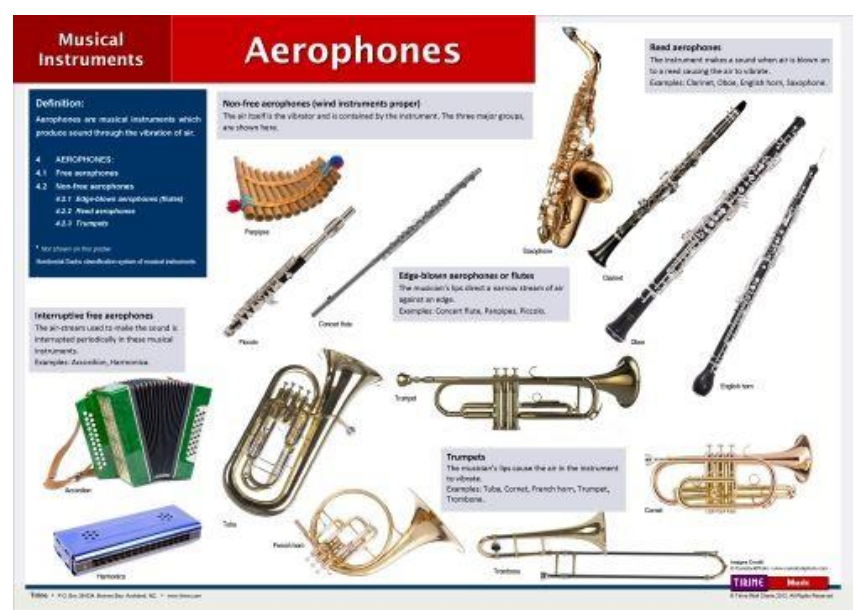




\section{Membranophone}

Instrument membranophone adalah instrument yang sumber bunyinya berasal dari membrane atau kulit dari instrument tersebut. Instrument ini umumnya dimainkan dengan cara dipukul, baik dengan telapak tangan atau menggunakan alat pemukul. Yang termasuk dalam klasifikasi instrument membranophone adalah kendang, snare drum, tympani, tifa, bongo, rebana, bass drum, dan sebagainya.

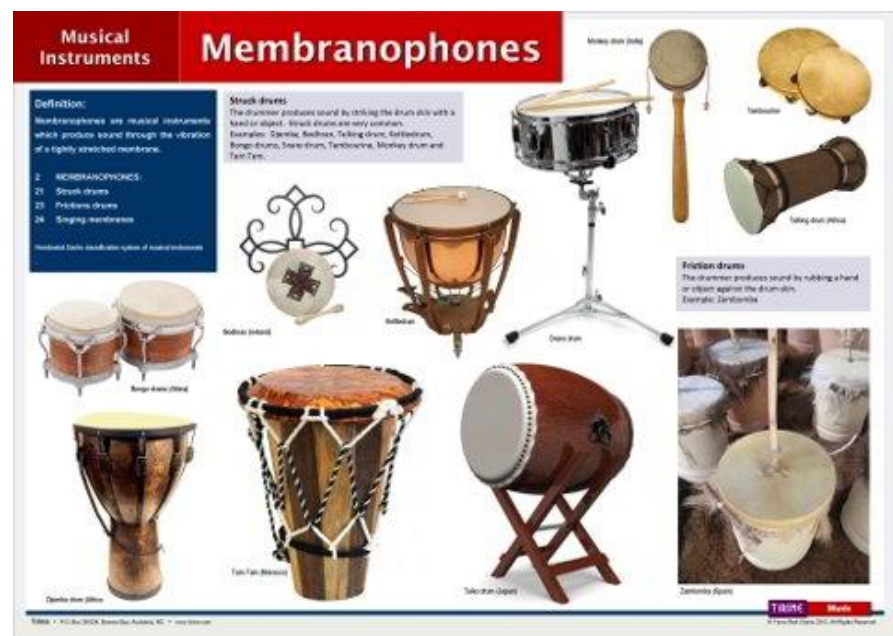

\section{Electrophone}

Instrument electrophone adalah instrument yang bunyinya dihasilkan dari getaran atau osilasi listrik. Yang termasuk instrument electrophone adalah keyboard, organ, gitar elektrik, drum elektrik, dan sebagainya. 


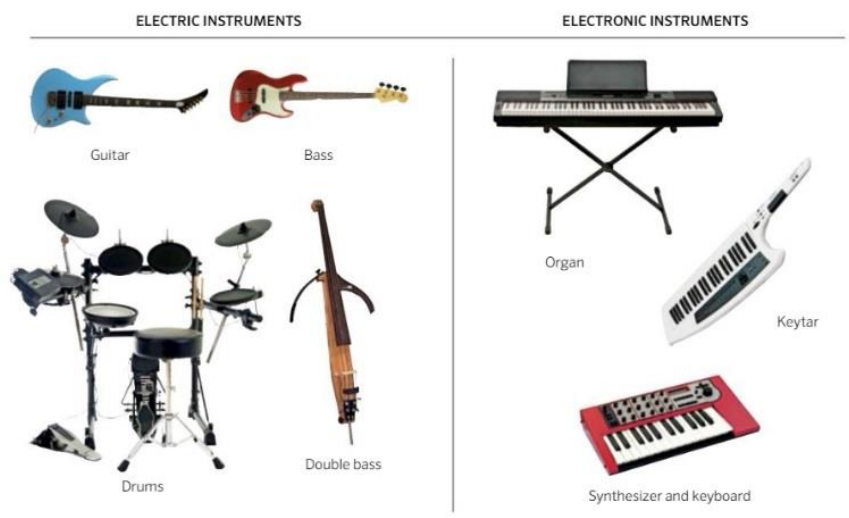

C. Klasifikasi Instrument Musik Berdasarkan Cara Memainkannya

Selain dari warna suaranya, karakter instrument musik juga dapat dilihat dari cara memainkannya. Berdasarkan cara memainkannya, instrument music dibagi dalam beberapa kelompok, dipetik, dipukul, ditiup, digoyang, dan ditekan.

1. Instrument Musik Petik

Instrumen petik adalah instrument music yang dimainkan dengan cara dipetik. Instrument yang dimainkan dengan cara dipetik adalah gitar, siter, sasando, kecapi, ukulele, dan sebagainya. 


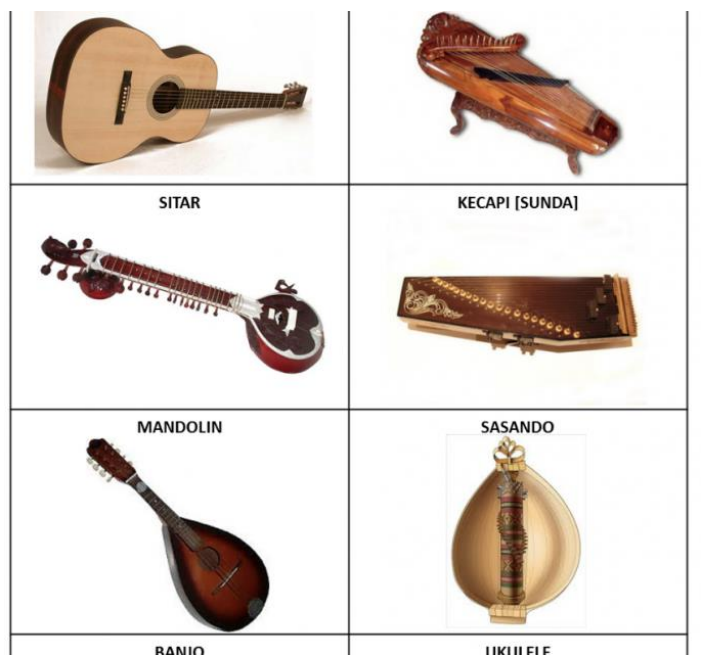

2. Instrument Musik Pukul

Instrument pukul adalah instrument musik yang dimainkan dengan cara dipukul, baik dipukul dengan tangan atau dipukul dengan menggunakan stik pemukul. Yang termasuk instrument music pukul adalah kulintang, cylophone, kendang, ketipung, tifa, bongo, marimba, drum, dan sebagainya.

Jenis Alat Musik Pukul

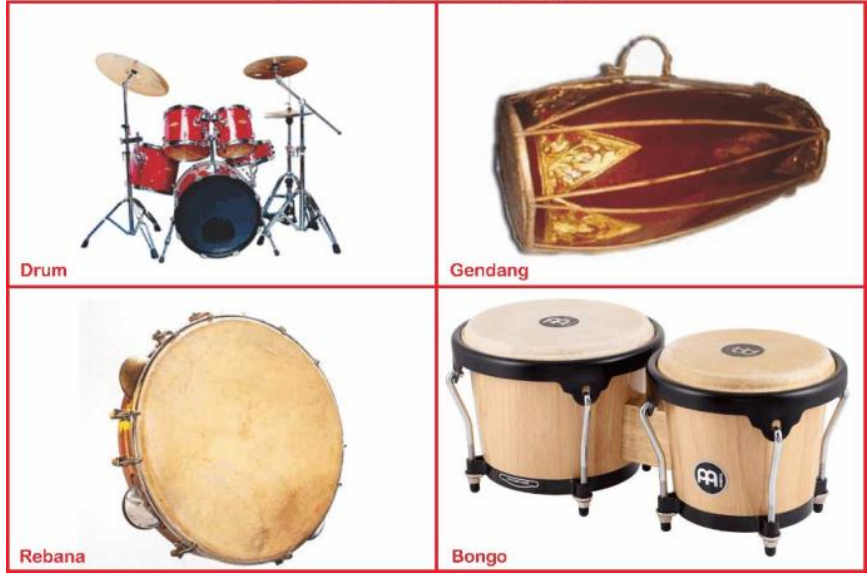


3. Instrument Musik Tiup

Instrument tiup adalah instrument music yang dimainkan dengan cara ditiup. Yang termasuk instrument tiup adalah flute, trombone, seruling, recorder, clarinet, tuba, saluang, slompret, dan sebagainya.

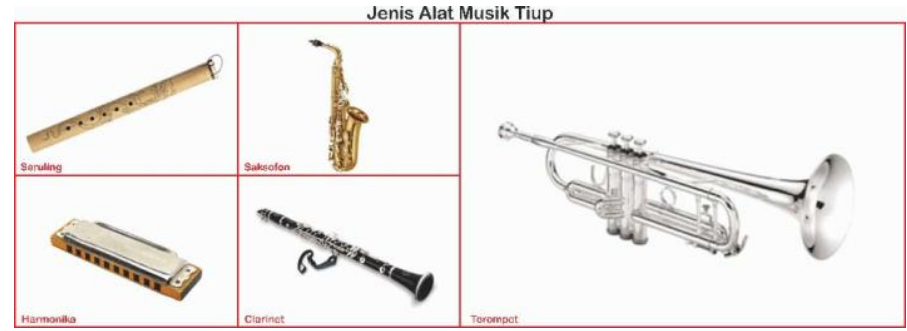

4. Instrument Musik Goyang

Instrument goyang adalah instrument music yang dimainkan dengan cara digoyang agar dapat bergetar dan menghasilkan suara. Yang termasuk instrument music goyang adalah kulintang, marakas, tamborin, dan sebagainya.

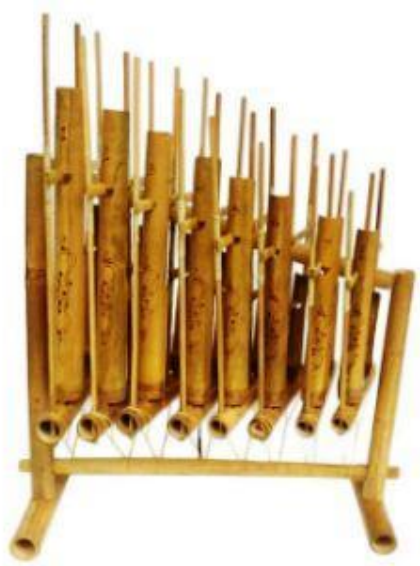




\section{Instrument Musik Tekan}

Instrument tekan adalah instrument music yang dimainkan dengan cara diberi tekanan dengan menggunakan jari. Instrument ini biasanya berbilah dalam susunan khusus. Yang termasuk instrument musik tekan adalah keyboard, piano, akordeon, organ dan sebagainya.

Jenis Alat Musik Tekan

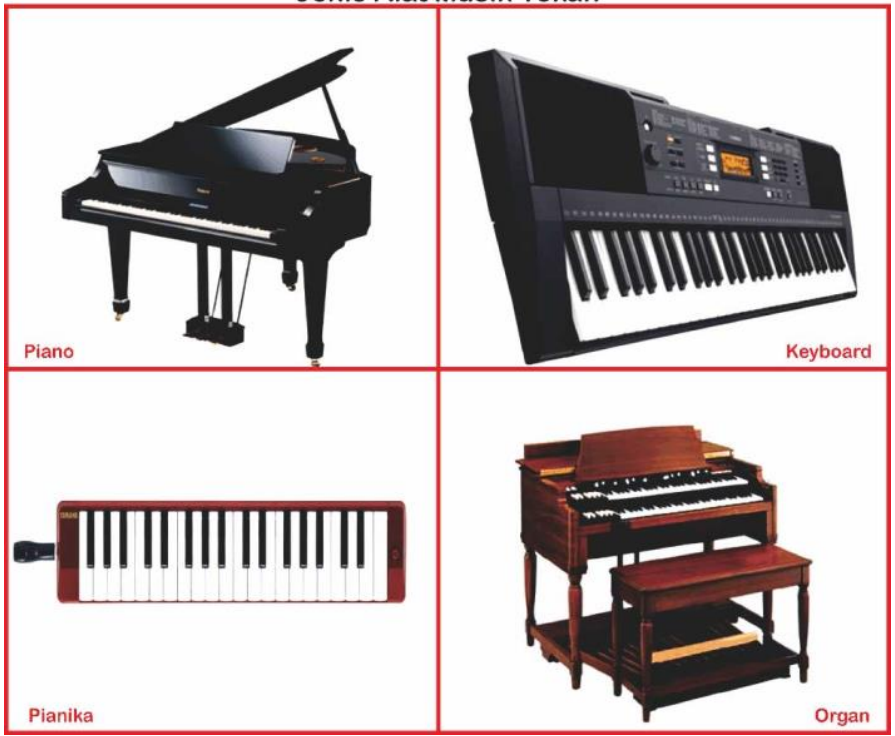


CHORD/AKORD

Dalam permainan musik terdapat chord atau akord yang biasanya digunakan untuk mengiringi suatu lagu. Chord atau akord adalah salah satu elemen utama musik yang dapat memberikan gambaran sederhana dari suatu karya musik (Timotius dan Prayogo, 2010). Dalam sebuah lagu chord dapat dimainkan secara terputusputus maupun terus-menerus sehingga membentuk dinamika dalam irama lagu tersebut. Karena merupakan elemen utama dalam mengiringi sebuah lagu, chord menentukan irama dan genre dari suatu lagu. Chord dapat dimainkan dengan alat musik yang dimainkan dengan cara membunyikan beberapa nada sekaligus seperti piano dan gitar. Dalam teori musik, terdapat berbagai macam jenis chord dengan aturan pembentukannya masingmasing. Akord atau chord merupakan satuan nada yang dibunyikan secara serentak (Hendro, 2007). Karena merupakan satuan nada, Chord tidak hanya terdiri atas satu nada, tetapi beberapa nada yang berbeda. Chord juga umumnya disebut triad karena terdiri atas tiga nada, yaitu nada ke-1, nada ke-3, dan nada ke-5 dari tangga nada penyusunnya (Wisnudisastra, 2009).

\section{A. Akord Pokok/ Primer}

Akor-akor Primer (Pokok), adalah akor-akor dari sebuah tangganada yang mempunyai peran dan fungsi yang lebih dibanding dengan akor-akor lain. Yang termasuk akor-akor primer (pokok), adalah akor-akor pada tingkat I, IV, dan V. Dalam tangganada mayor, maka akor-akor I, IV, dan V adalah akor-akor dengan kualitas mayor. Sedangkan dalam tangganada minor, 
akor I, dan IV adalah akor-akor dengan kualitas minor, dan akor $\mathrm{V}$ adalah akor dengan kualitas mayor. Perlu dijelaskan di sini, bahwa dalam pembahasan akor (harmoni), tangganada minor yang biasa digunakan adalah tangganada minor harmonis, sehingga akor $V$ akan selalu mempunyai kualitas mayor.

Ada tiga akord pokok dalam setiap tangga nada diatonis mayor ataupun minor, yaitu akord I - tonika (tonic chord); akord V - dominan (dominant chord) dan akord IV - subdominan (subdominant chord).

Contoh : Dalam T.N C mayor, akor I - tonika dikenal dengan akord C mayor. Akor $\mathrm{V}$-dominan dikenal dengan akord G mayor. Akor IV - subdominan dikenal sebagai $\mathrm{F}$ mayor.

\section{B. Akord Sekunder}

Yakni akord II (super tonika), III (median), \& VI (submedian). Akord I, III, \& VI dalam susunan T.N mayor maupun T.N minor pasti merupakan akord minor.

Pada mata kuliah ini lebih ditekankan pada Akord Primer, dan bagaimana mahasiswa mampu mengiringi lagu anak sederhana dengan menggunakan akord Primer.

\section{Mengiringi Lagu Anak}

Seorang Guru PAUD akan lebih istimewah jika memiliki keahlian memainkan salah satu instrument musik. Salah satu instrument musik yang rata-rata dimiliki di sekolah PAUD adalah instrument keyboard, namun rata-rata guru PAUD belum memiliki kemampuan untuk mengiringi siswanya dalam bernyanyi. Padahal dengan bantuan instrument musik akan sangat membantu baik bagi guru maupun siswa untuk mendapatkan nada yang tepat. 
Lagu-lagu di sekolah PAUD rata-rata adalah lagu anak sederhana yang sangat memungkinkan untuk diiringi dengan menggunakan akord Primer. Tentunya butuh keberanian dan usaha guru untuk mulai mengiringi siswa saat mernyanyi. Dengan nada dasar yang tepat, tentu menyanyi akan menjadi kegiatan yang sangat menyenangkan, dan membiasakan telinga untuk menirukan suara yang didengar akan melatih dan mengasah musikalitas anak. Mari mencoba untuk mengiringi lagu anak dengan menggunakan instrument keyboard.

Keyboard adalah alat musik berbentuk bidang atau papan (board) yang memiliki bilah-bilah (tuts) hitam dan putih sebagai nada-nada yang terbentuk secara berurutan dan matematis berdasarkan frekwensi getaran suaranya. Tuts tersebut berwarna hitam dan putih. Alat musik keyboard dulunya berasal dari alat musik yang bernama Ugab. Kemudian piano pun mulai dikenal, dan selanjutnya menjadi organ. Pada masa Karel Agung, piano dan organ mulai banyak dikenal masyarakat Eropa. Selanjutnya, pada masa komputerisasi, Organ tersebut berevolusi menjadi Keyboard. Singkatnya, alat musik keyboard pada dasarnya memiliki teknik memainkan yang tidak jauh berbeda dengan piano maupun organ. Hanya saja keyboard merupakan alat musik yang cara pengoperasiannya sudah dipengaruhi oleh program-program yang berbasis komputer.

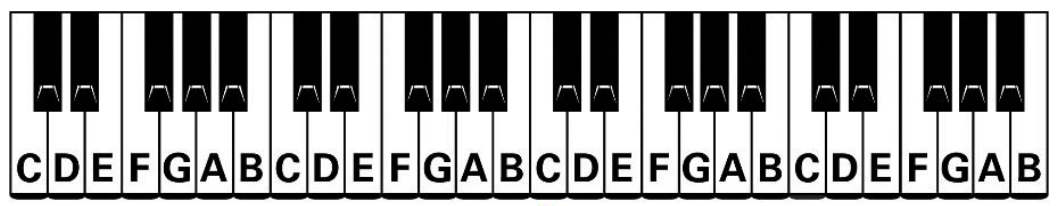

middle $\mathrm{C}$ 

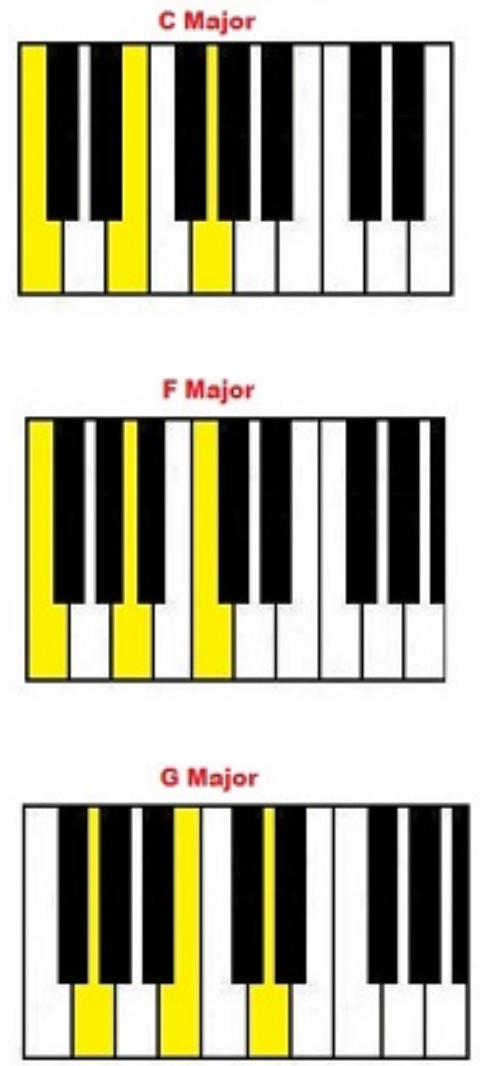

D. Memainkan Instrumen

Belajar keyboard khususnya bagi pemula memang merupakan hal yang sangat berat untuk dimulai, tetapi jika anda mau berlatih dengan keras setiap hari, anda pasti bisa. Inti dari latihan setiap hari atau beberapa kali dalam seminggu agar melatih jari-jemari anda lihai dalam memainkan beberapa lagu. Jika anda masih susah dalam membawakan lagu, mungkin bisa anda mulai dengan lagu- 
lagu yang tidak begitu berat, artinya perpindahan kunci nada tidak terlalu banyak.

Belajar keyboard tidak hanya anda belajar bagaimana memainkan sebuah keyboard, akan tetapi anda juga harus bisa menguasai perangkat tersebut, karena inti dari belajar keyboard sesungguhnya adalah melatih anda agar bisa menjadi seorang arranger, artinya anda akan bisa membuat sebuah lagu anda sendiri atau membuat kembali lagu orang lain lewat bunyi-bunyi instrumen yang ada di keyboard tersebut. Menjadi arranger yang saya maksud adalah anda bisa menciptakan sebuah style lagu yang mirip atau kreasi anda sendiri. Memang, bermain keyboard ujung-ujungnya pasti "kebelet" mau bikin style sebuah lagu. Karena kalau sudah mahir, banyak orang berusaha membuat style untuk lagu-lagu terbaru dari keyboard yang mereka miliki.

Oke, mungkin terlalu tinggi pengharapannya, namun sekali lagi untuk sukses belajar keyboard, bagi para pemula disarankan agar anda :

1. Menghafal kunci nada, agar jemari anda terlatih berpindahpindah.

2. Mulailah membedakan bunyi-bunyi semua instrument yang ada.

3. Jangan memulai belajar keyboard dengan style yang sudah jadi.

4. Cari forum yang membahas bagaimana belajar keyboard yang efektif.

5. Jangan sungkan bertanya kepada orang yang lebih tahu dan jangan malas cari info dari internet.

6. Practice makes perfect. 
Bermain musik adalah suatu keahlian dan berhubungan dengan skill/ketrampilan. Tidak ada satu ketrampilan/keahlian manapun yang dapat dipelajari dalam semalam atau hanya beberapa jam, beberapa hari saja. Hal ini perlu digaris bawahi dan direnungkan sebelum anda memutuskan untuk belajar memainkan keyboard ataupun piano.

Menguasai alat musik keyboard atau piano tidak bergantung pada tingkat kecerdasan seseorang, tapi lebih didasarkan pada tingkat ketekunan dan kemauan berlatih pada orang yang bersangkutan. Karena, kemauan dan ketekunan jauh lebih menentukan daripada sebuah kecerdasan. Dan ini adalah pemahaman pertama yang perlu anda ketahui sebelum kita melangkah lebih jauh.

Apa sih perbedaan antara Keyboard dan Piano? Pada dasarnya, keyboard adalah pengembangan dari piano klasik yang menggunakan tenaga elektrik. Namun seiring dengan perkembangan teknologi, sebuah keyboard kini tidak hanya mampu menghasilkan suara yang menyerupai sebuah piano tetapi juga beragam suara yang menyerupai instrumen musik lainnya. Selain itu, sebuah keyboard juga dapat difungsikan untuk memainkan beberapa alat musik pada saat yang bersamaan. Bahkan tidak berlebihan jika pada masa sekarang ini sebuah keyboard dapat memperdengarkan alunan musik orkestra yang di mainkan oleh hanya satu orang.

Hal ini sangat jauh berbeda dengan sebuah piano yang hanya mampu memperdengarkan satu jenis suara pada saat yang bersamaan. Walaupun demikian, pada saat sekarang telah di ciptakan piano elektrik yang 
kemampuannya tidak jauh berbeda dengan sebuah keyboard. Seperti kebanyakan alat musik yang lain, memainkan keyboard juga membutuhkan sinkronisasi yang baik antara kedua belah tangan. Pada umumnya, tangan kanan dipergunakan untuk melantunkan melody lagu, sedangkan tangan kiri memainkan chord-chord yang mengiringi alunan melody tersebut. Bagi pemula, memecah perhatian seperti ini agak sulit di lakukan. Namun, jika terus berlatih dan berlatih, niscaya akan terbiasa dan tidak merasa sulit lagi.

\section{E. Latihan Penjarian Dalam Bermain Keyboard}

Contoh berikut ini hanya penjarian dasar untuk bermain piano dan keyboard. Sebenarnya ada banyak bentuk latihan penjarian untuk bermain keyboard atau piano.

TANGAN KIRI DAN TANGAN KANAN :

JARI JEMPOL $=1$

JARI TELUNJUK = 2

JARI TENGAH = 3

JARI MANIS $=4$

JARI KELINGKING = 5
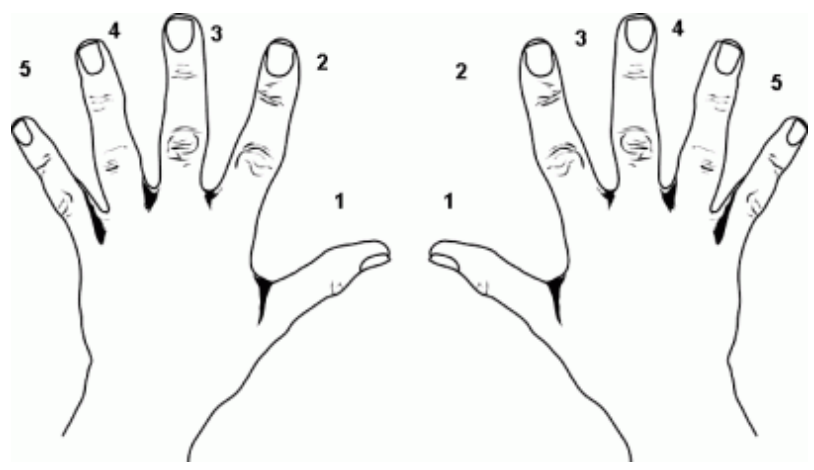


\section{Latihan 1}

Untuk nada Do - Re - Mi - Fa - Sol atau tuts C - D - E - F $\mathrm{G}$, penjarian tangan kanan adalah :

$\mathrm{Do} / \mathrm{C}=1$

$\mathrm{Re} / \mathrm{D}=2$

$\mathrm{Mi} / \mathrm{E}=3$

$\mathrm{Fa} / \mathrm{F}=4$

Sol / $\mathrm{G}=5$

Penjarian tangan kiri adalah :

Do $/ C=5$

$\operatorname{Re} / D=4$

$\mathrm{Mi} / \mathrm{E}=3$

$\mathrm{Fa} / \mathrm{F}=2$

$\mathrm{Sol} / \mathrm{G}=1$

Petunjuk :

- Ketika menekan tuts, hanya satu jari yang menekan tuts, sedang jari lain diangkat dan tidak menyentuh tuts.

- Awali latihan dengan satu tangan (kanan atau kiri) secara bergantian terlebih dahulu.

- Mainkan not tersebut naik turun/bolak balik, dari do ke sol dan sol ke do.

- Lalu kombinasikan kedua tangan secara serentak memainkan not yang sama dengan jarak satu oktaf.

- Lakukan mulai dari tempo lambat dan perlahan cobalah untuk mempercepat tempo. 


\section{Latihan 2}

$$
\begin{aligned}
& \text { Nada Do }-\mathrm{Re}-\mathrm{Mi}-\mathrm{Fa}-\mathrm{Sol}-\mathrm{La}-\mathrm{Si}-\mathrm{Do} \\
& \text { atau tuts } \mathrm{C}-\mathrm{D}-\mathrm{E}-\mathrm{F}-\mathrm{G}-\mathrm{A}-\mathrm{B}-\mathrm{C}(1 \mathrm{Oktaf}) \text {. }
\end{aligned}
$$

Penjarian tangan kanan adalah :

Do $/ C=1$

$\operatorname{Re} / \mathrm{D}=2$

$\mathrm{Mi} / \mathrm{E}=3$

$\mathrm{Fa} / \mathrm{F}=1$

Sol / $\mathrm{G}=2$

La $/ \mathrm{A}=3$

$\mathrm{Si} / \mathrm{B}=4$

Do $/ C=5$

Penjarian tangan kiri adalah :

Do $/ C=5$

$\operatorname{Re} / D=4$

$\mathrm{Mi} / \mathrm{E}=3$

$\mathrm{Fa} / \mathrm{F}=2$

Sol / $\mathrm{G}=1$

La $/ \mathrm{A}=3$ 
$\mathrm{Si} / \mathrm{B}=2$

Do / $\mathrm{C}=1$

Petunjuk :

- Ketika menekan tuts, hanya satu jari yang menekan tuts, sedang jari lain diangkat dan tidak menyentuh tuts.

- Awali latihan dengan satu tangan (kanan atau kiri) secara bergantian terlebih dahulu.

- Mainkan not tersebut naik turun/bolak balik, balik, dari do ke sol dan sol ke do.

- Lalu kombinasikan kedua tangan secara serentak memainkan not yang sama dengan jarak satu oktaf.

- Lakukan mulai dari tempo lambat dan perlahan cobalah untuk mempercepat tempo.

- Jika sudah mulai menguasai, lakukan latihan ini dengan dua tangan secara serentak, dengan arah berlawanan. Tangan kiri dimulai dari Do rendah ke Do tinggi sedangkan tangan kanan dari Do tinggi ke Do rendah.

Mulailah untuk mencoba mengiringi lagu anak menggunakan akord Primer dengan penjarian yang baik. Semakin sering anda berlatih, maka akan semakin baik kemampuan anda dalam mengiringi lagu. Selamat belajar... 


\section{Assalamu'alaikum}
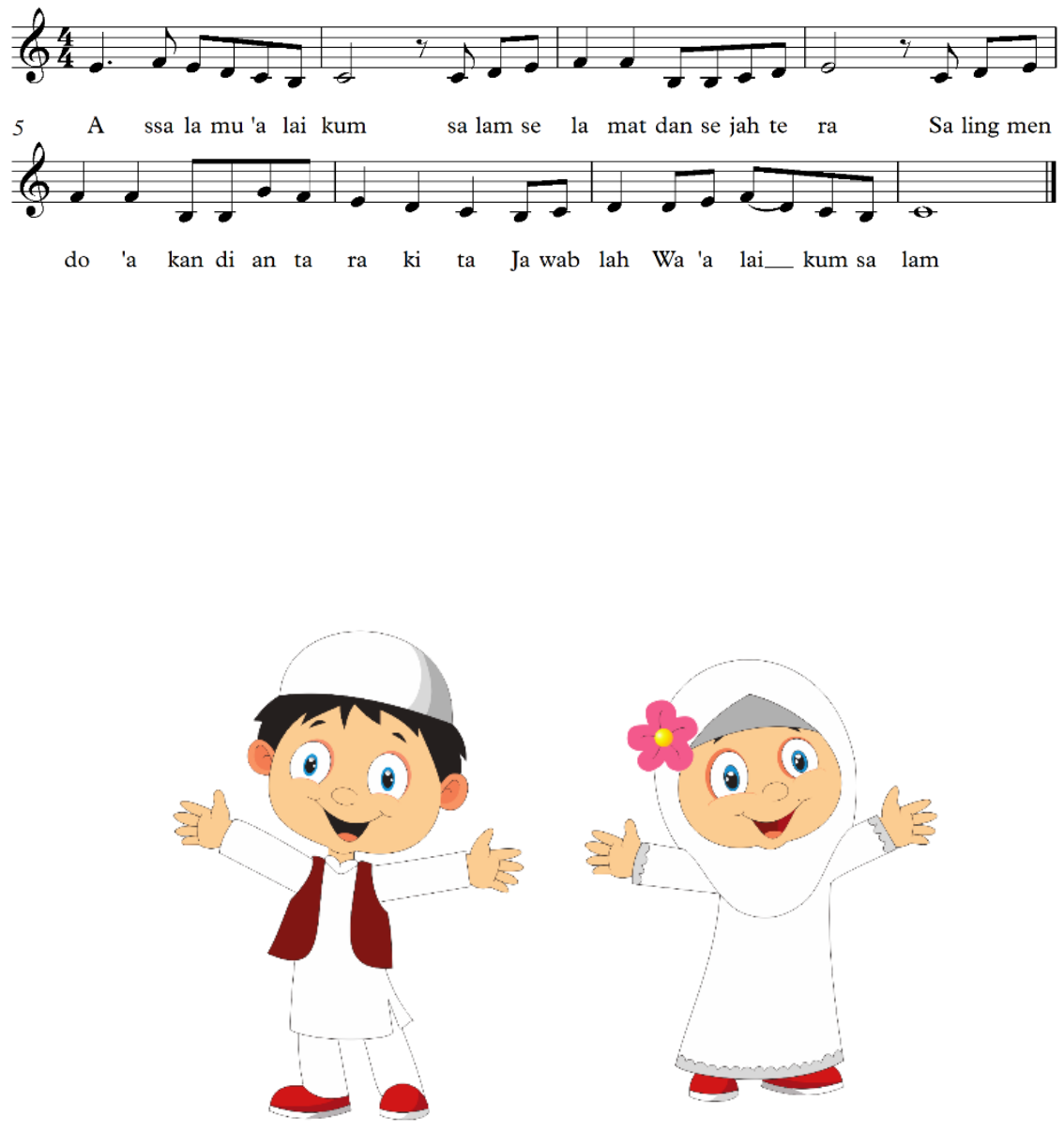


\section{Hati Gembira}

A.T Mahmud
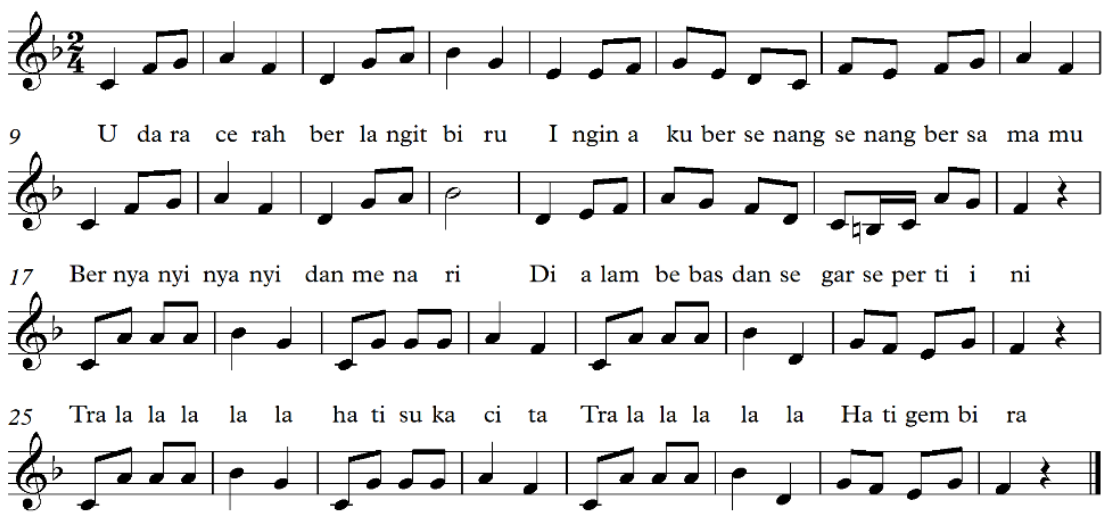

Tra la la la la la ha ti su ka ci ta Tra la la la la la Ha ti gem bi ra

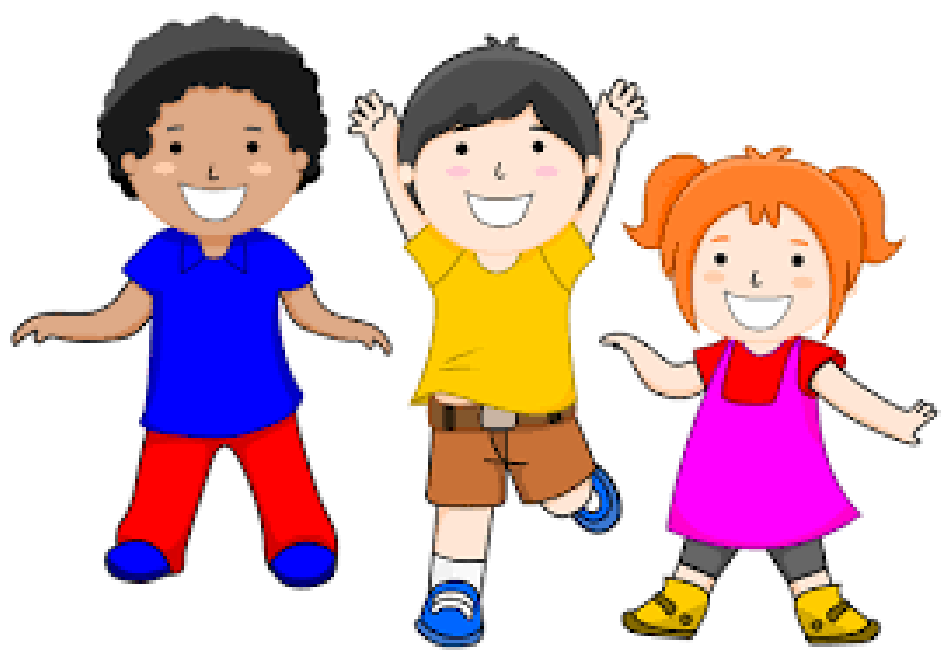




\section{Irama Desa}

Mochtar Embut

Iskandar
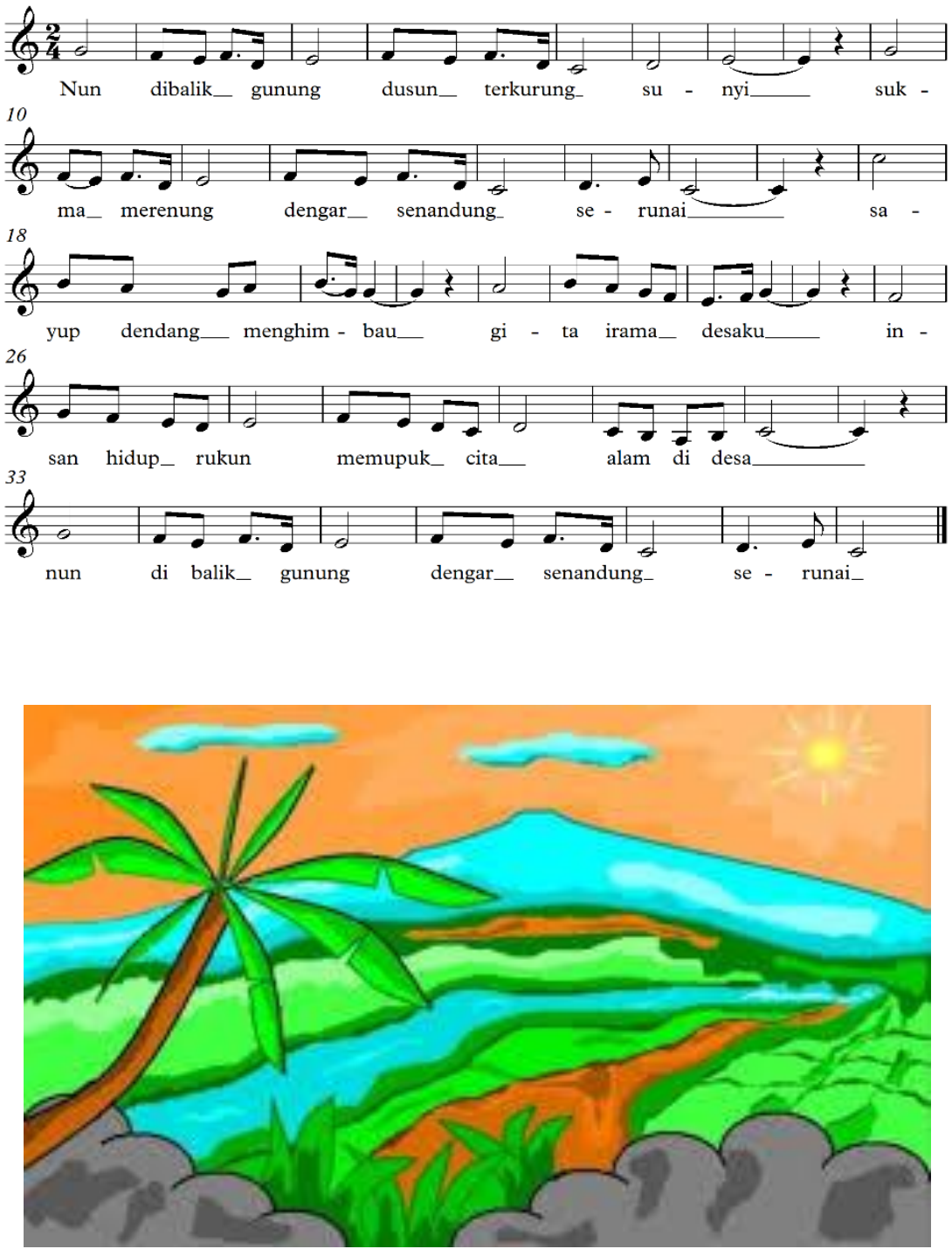


\section{Lagu Gembira}

Andante

Ibu Sud

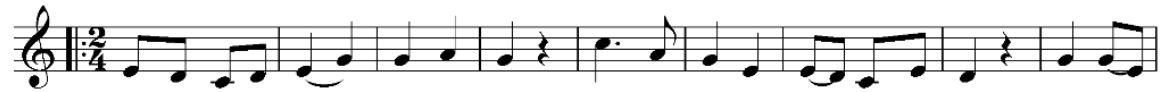

Ber nya nyi ki ta__ ber nya nyi ka re na ber gi_rang ha ti Ber so_

10 Ber si ul ki ta_ ber si ul tan da nya ki ta_berkumpul Ber so_
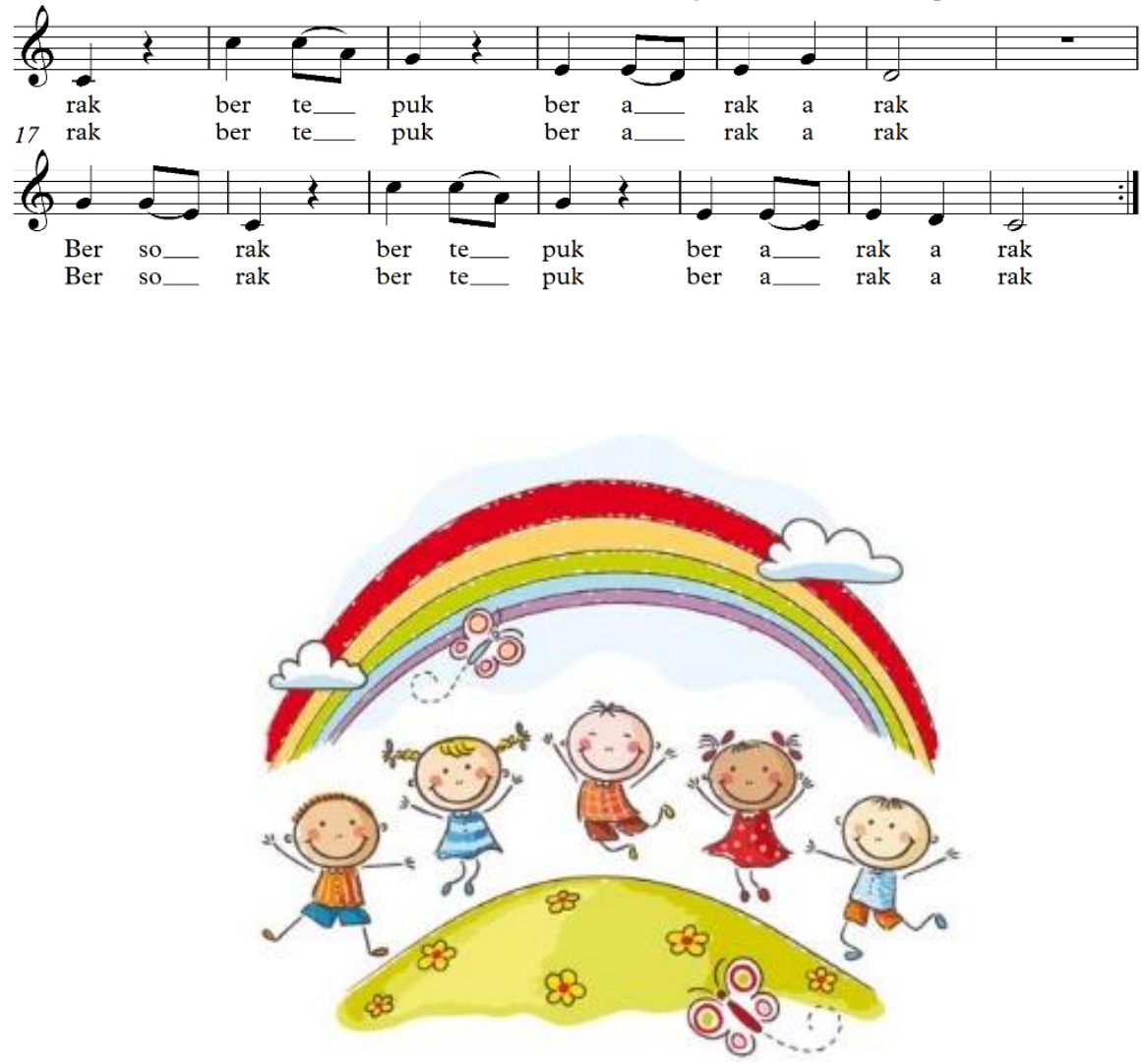


\section{Aku Anak Indonesia}

A.T Mahmud

Andante
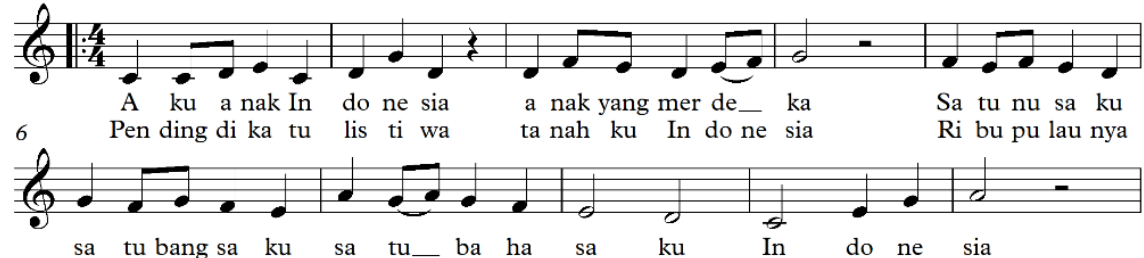

11 ra gam su ku nya sa tu ji wa ra ga nya In do ne sia
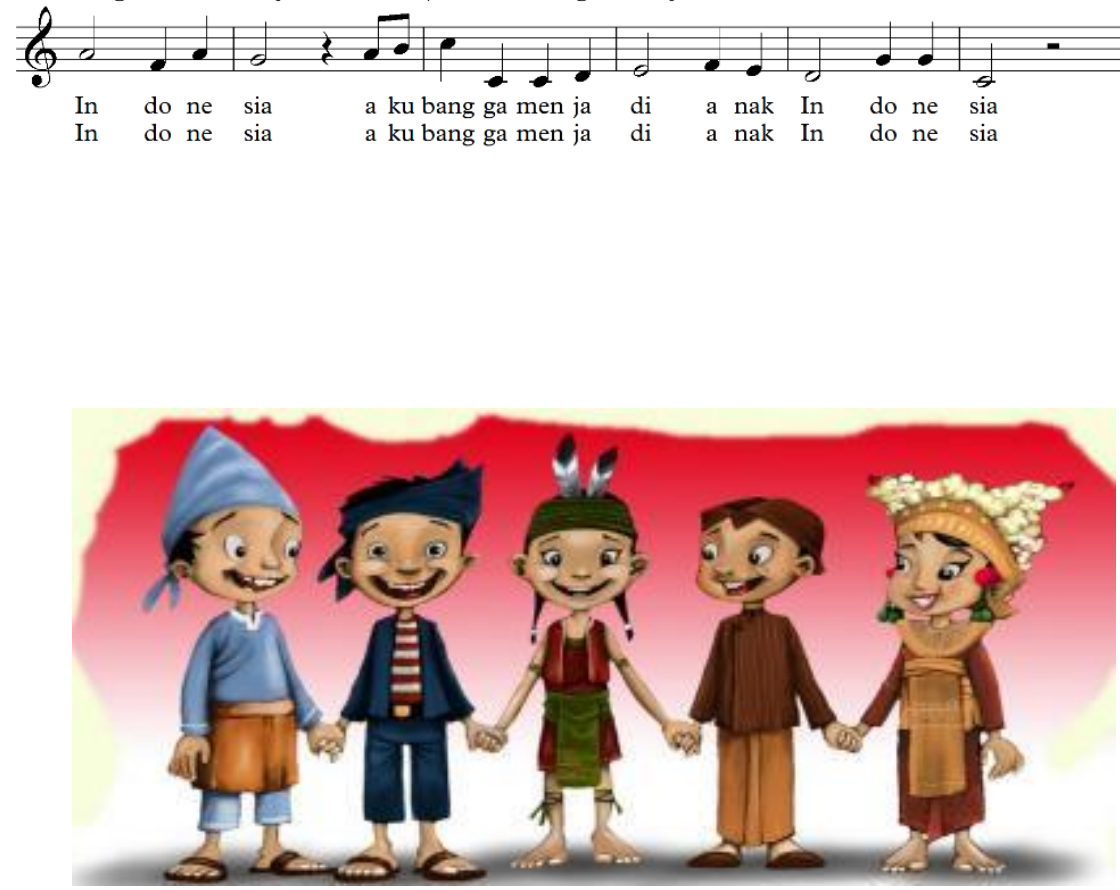


\section{Naik Becak}

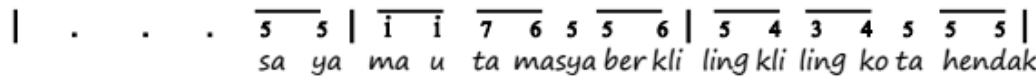

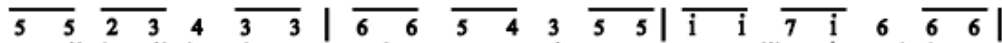
me li hat li hat ke ra mai an yanga da sa ya panggilkan be cak ke re

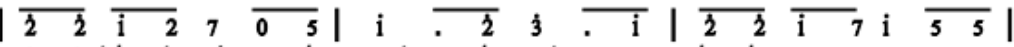
ta takberku da be cak be cak co ba ba wa saya sa ya

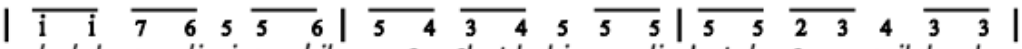
duduk sen di ri sambil mengangkat kaki me li hat dengan a syikke ka

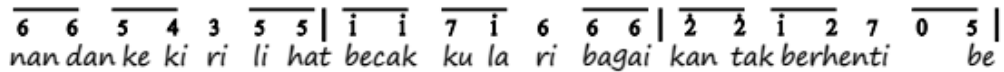

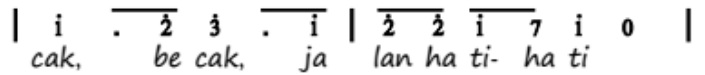




\section{Ibu Kita Kartini \\ W.R Supratman}

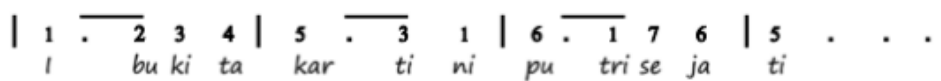

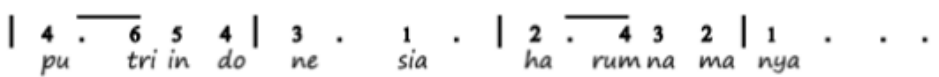

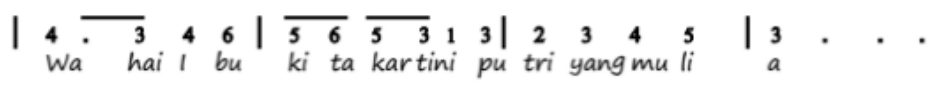

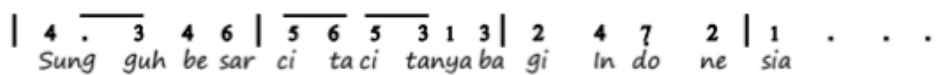


$\|: \overline{005}|\overline{1.1} \overline{1.2}| \overline{333} \overline{1.4}|\overline{3.2} \overline{712}| \overline{1.15} \overline{05} \mid$ (5)
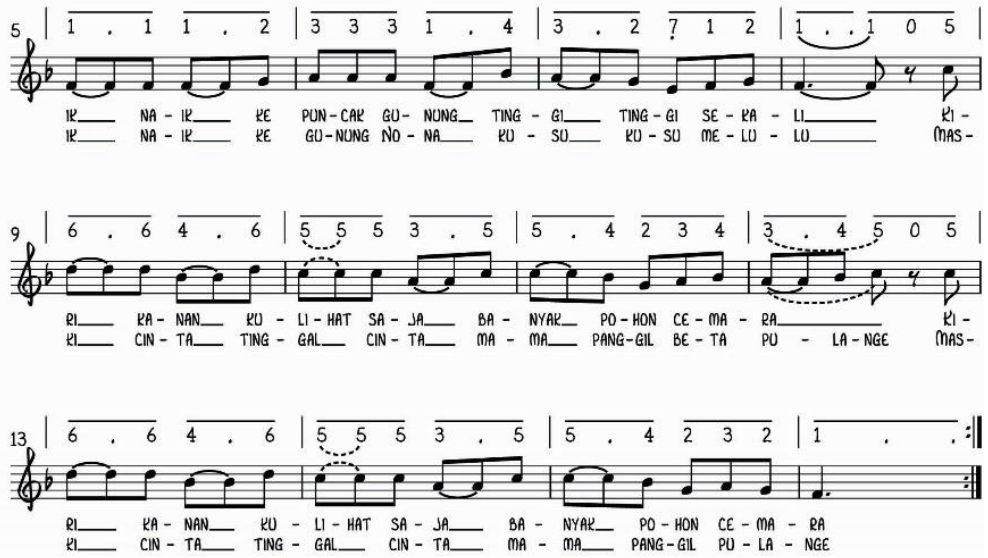


\section{NAIK DELMAN}

\section{pak kasur}

$\overline{5}|\overline{11} \overline{13} \overline{55} \overline{53}| \overline{66} \overline{63} 5 \overline{5} \mid$ pa-da hari minggu kuturut ayah ke kota na-

$\left|\begin{array}{lllllll}\overline{11} & \overline{13} & \overline{55} & \overline{53} & \overline{66} & \overline{34} & 2 . \overline{5}\end{array}\right|$

ik delman istimewa kududuk di muka ku-

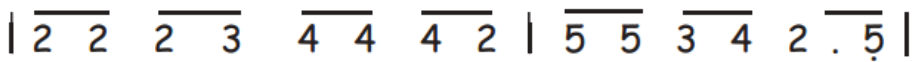
duduk samping pak kusir yang sedang bekerja me-

$|\overline{22} \overline{23} \overline{44} \overline{42}| \overline{54} \overline{32} 1$. $\mid$

ngendali kuda supaya baik jalannya

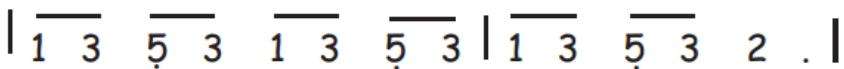
tuk tik tak tik tuk tik tak tik tuk tik tak tik tuk

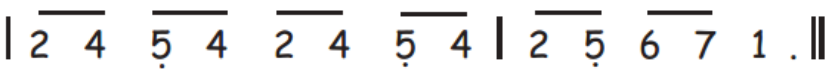
tuk tik tak tik tuk tik tak suara s'patu kuda 


\section{Burung Hantu}

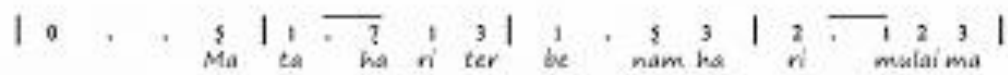

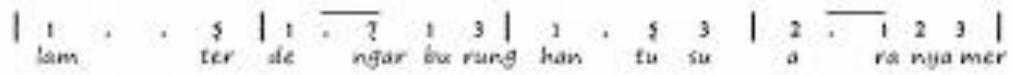

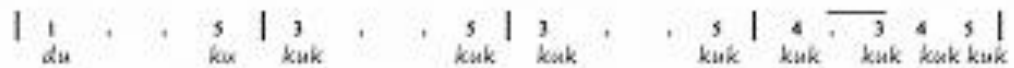

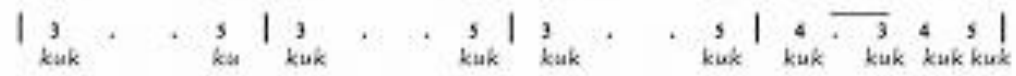

$$
\begin{aligned}
& \left.\right|_{k u k} ^{3}+\infty \quad+0
\end{aligned}
$$




\section{Potong Bebek Angsa}

$D=$ do $4 / 4$

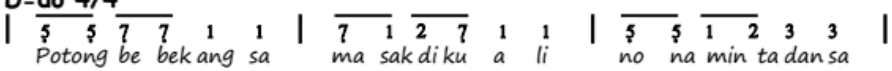

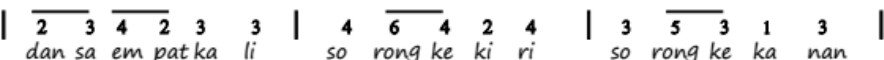

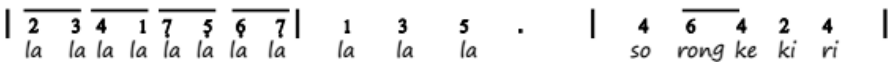

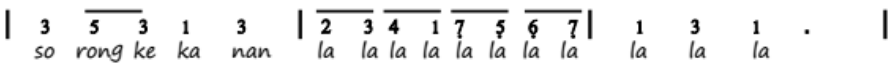




\section{Ampar-ampar Pisang}

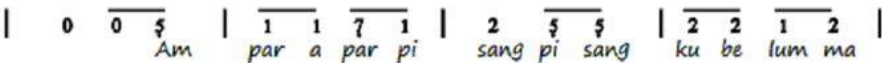

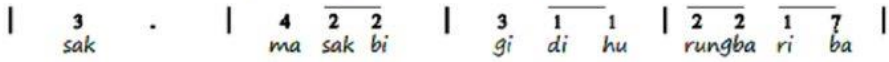

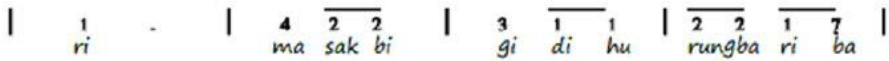

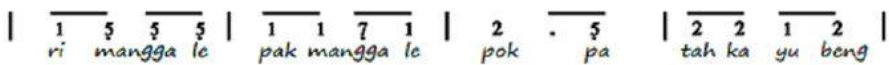

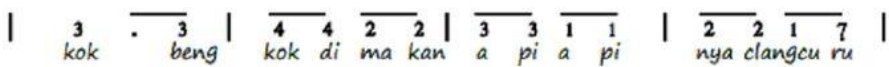

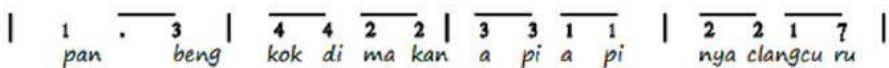

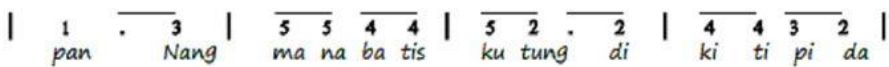

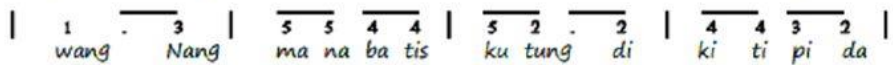

$$
\begin{aligned}
& \text { I } 1 \text { Wang } \quad \text { | }
\end{aligned}
$$




\section{Indonesia Pusaka}

Ismail Marzuki

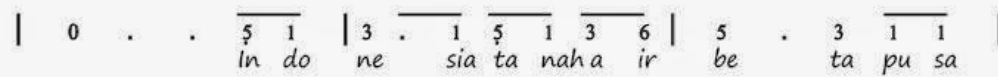

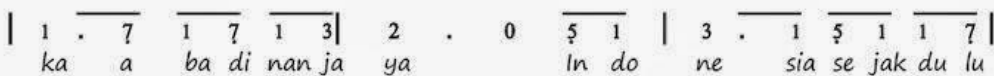

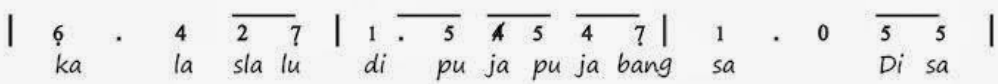

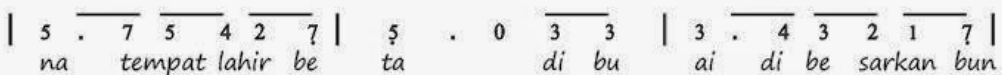

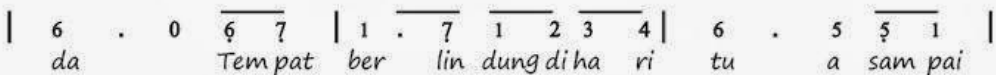

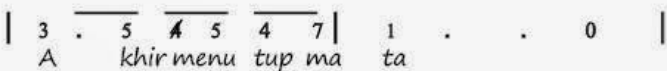




\section{Pergi Belajar}

$$
\begin{aligned}
& \text { Ibu sud }
\end{aligned}
$$

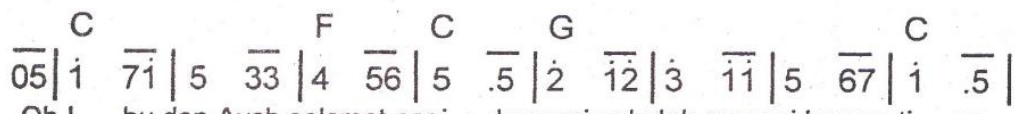

$$
\begin{aligned}
& \text { OhI bu dan Ayah selamat pagi kupergi sekolah sampai kaunanti se- }
\end{aligned}
$$

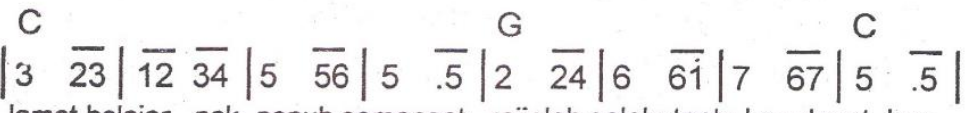

$$
\begin{aligned}
& \text { lamat belajar nak penuh semangat rajinlah selalu tentu kau dapat hor- }
\end{aligned}
$$

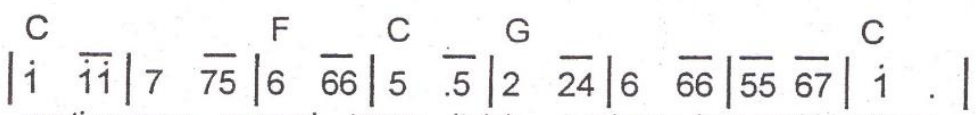




\section{Ambilkan Bulan Bu \\ ATMahmud}

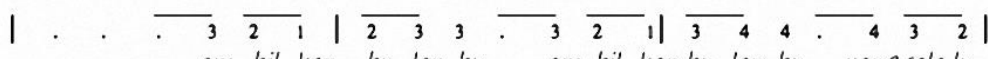
am bil kan bu lan bu am bil kanbu lan bu yangsela lu

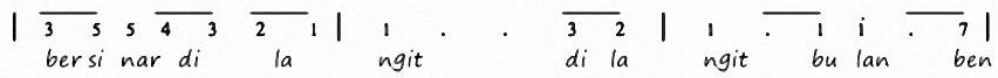

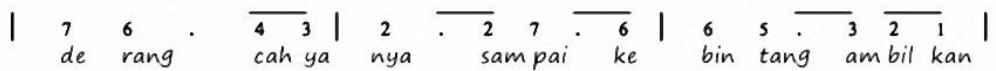

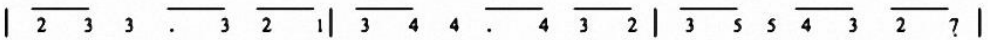
bu lanbu un tuk me ne rangi ti dur ku yang le lap di ma lam ge

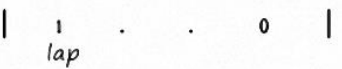




\section{Gundhul Pacul}

$\mathrm{Do}=\mathrm{C}$

4/4 Moderato

Lagu Jawa Tengah

\begin{tabular}{l|lllllllllllllllll}
$1 \mid$ & 3 & 1 & 3 & 4 & 5 & 5 & 0 & 7 & 1 & 7 & 1 & 7 & 5 & 0 & 1
\end{tabular} \mid Gundhul-gu-dhul pa - cul-cul gem - be - leng - an, Nyung

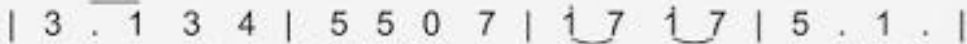
gi - nyunggi wa - kul-kul gem - be - leng - an, Wa -

| $3.5 .5 .\left|\begin{array}{llllllllllllll} & 3 & 4 & 4 & 5 & 4 & 3 & 1 & 4 & 3 & 1 & 1 & 0 & 1\end{array}\right|$ kul ngglim - pang se-ga - ne da-di sakla - tar, Wa

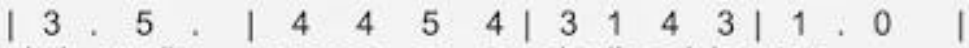
kul ngglim - pang se - ga - ne da-di sakla - tar 


\section{Kulihat Awan Seputih Kapas}

$4 / 4$

Tempo Agak lambat

$1=C$

$\begin{array}{llll}C & \mathrm{~F} & \mathrm{C} & \mathrm{F}\end{array}$

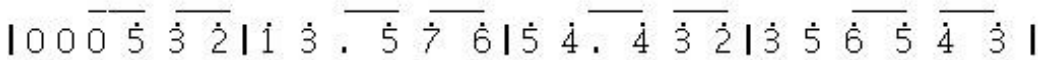
Kuli hat a wan Sepu tih kapas A rakberarakdi langitlu

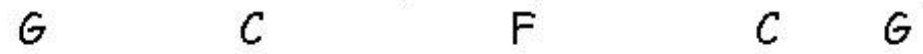

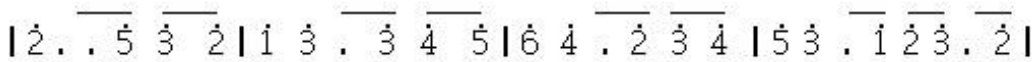
as Andai ku dapat Kesa naterbang a kanku raih kubawa pu C

| $1 ., \quad||$

lang 


\section{AKU ADALAH ANAK GEMBALA}

$1=6$

$2 / 4$

AT Mehmud

Andante (100)
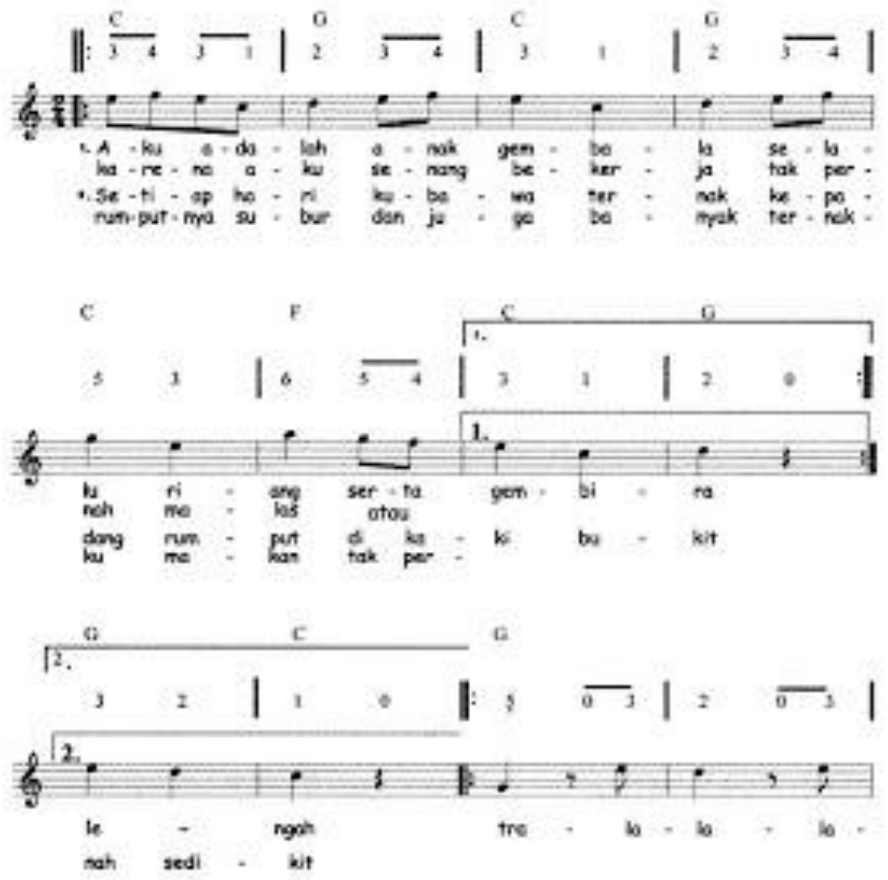


\section{Cemara}

$\mathrm{Do}=\mathrm{C}$

cipt : A.T Mahmud

\section{$3 / 4$}

Moderato

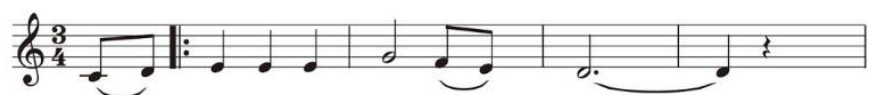

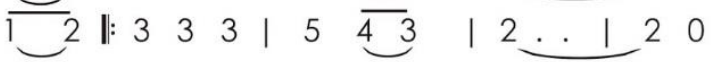

I. Ce - mara po - hon ram - ping

II. $\quad t i-k a$ a - ngin la - lu

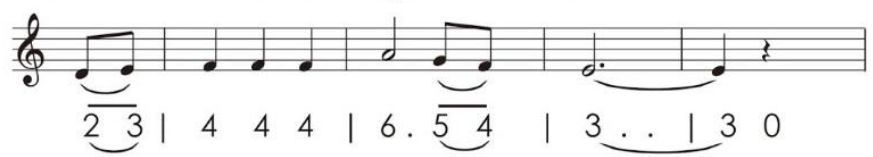

I. Da - un-nyaha - lus lang - sing

II. Me - nyentuh da - un cema - ra

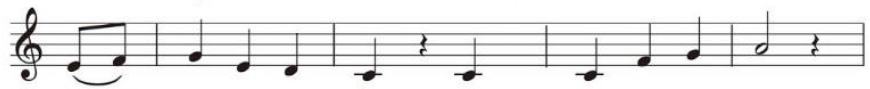

$$
\begin{array}{ll|lllllllllll|ll}
34 & 5 & 3 & 2 & 1 & 0 & 1 & \mid & 1 & 4 & 5 & 6 & 0
\end{array}
$$

I. Ber - ge-rak ge-rak ki - an ke-ma-ri

II. Ter - dengar de-sir di - te-li-nga-ku

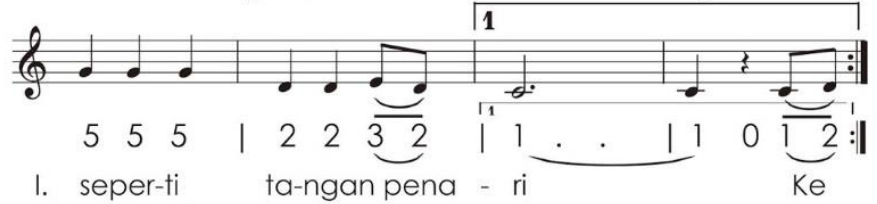

I. seper-ti ta-ngan pena - ri

II. Se-bu-ah la-gu mer - du

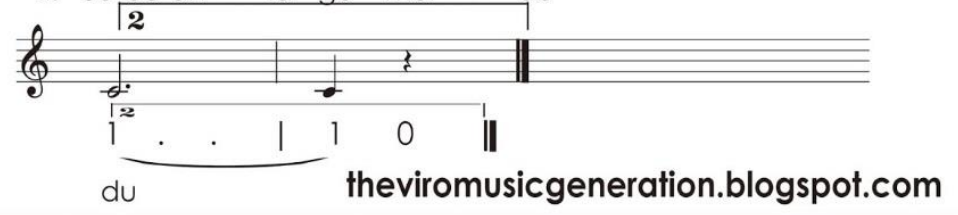


lenggang Padi

Bes $=$ Do $4 / 4$

Moderato

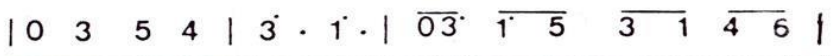

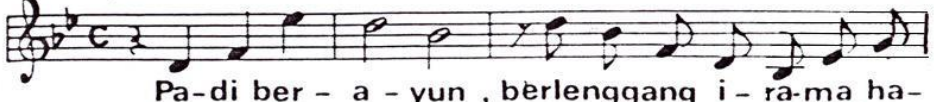

Tugas ber-jan-ji, pe-ta-ni pa-di berlim-

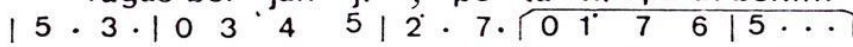

ra-pan. Me-lam-bai-lam-bai s'panjang ma-sa

pa-han . Lambang ba-ha - gia ...............

\begin{tabular}{llllllllllllllllll}
\hline 0 & 2 & 6 & 7 & 1 & $\ldots$ & 0 & 1 & 7 & 1 & $6 . \overline{4}$ & $6 \cdot 10$ & 1 & 7 & 1
\end{tabular}

Nu-sa Bangsa . Embun di batangmu, menghias

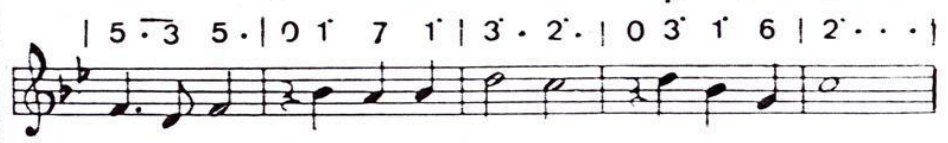

wajah-mu. Rat-na pemba-wa, se-jah-te-ra

$\mid \begin{array}{llllllllllllll}0 & 3 & .5 & 4 & 3^{*} \cdot 1 . & \overline{03} & \overline{1} & 5 & \overline{3} & \overline{4} 6\end{array}$

Lengganglah pa-di, lengyanglah i-ra-ma ba $\mid \begin{array}{lllllllllllllll}5.3 .1 & 0 & 3 & 4 & 5 & 2 & 2 & 7.1 & 0 & 2 & 6 & 7 & 1 & 1 & \ldots\end{array}$
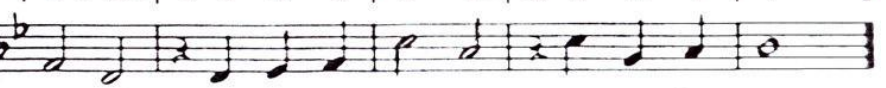

ha-gia. Di kau ha-ra-pan, bangsa mu-lia. 


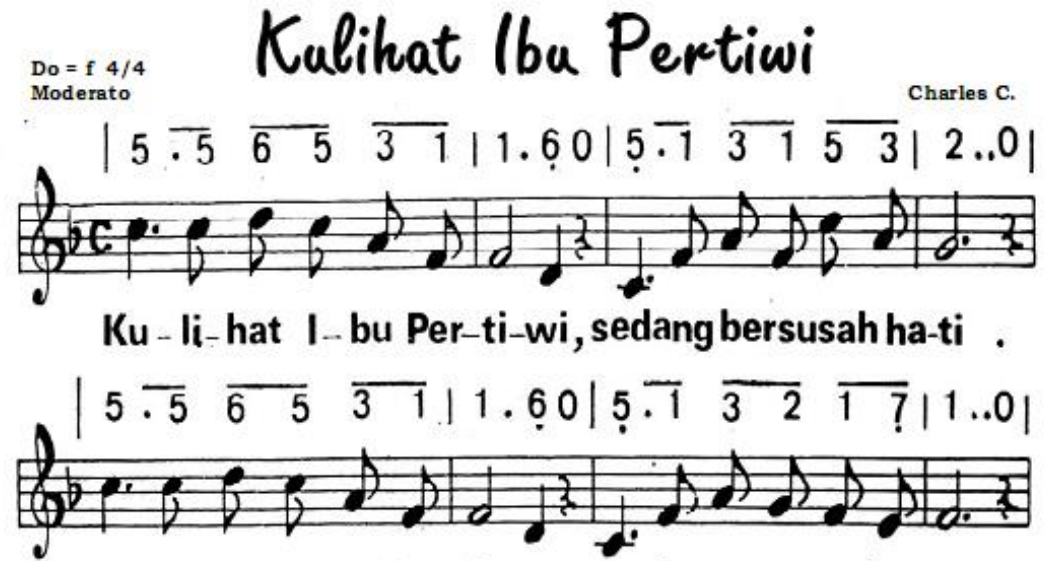

A - ir- ma-ta-mu ber-linang, masintanmu terkenang .

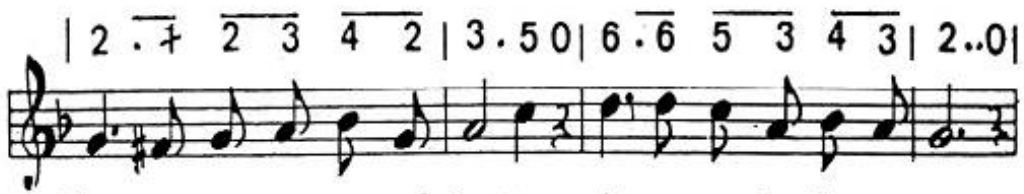

Hu-tan gunung sawah lautan, simpanan ke-kaya-an .

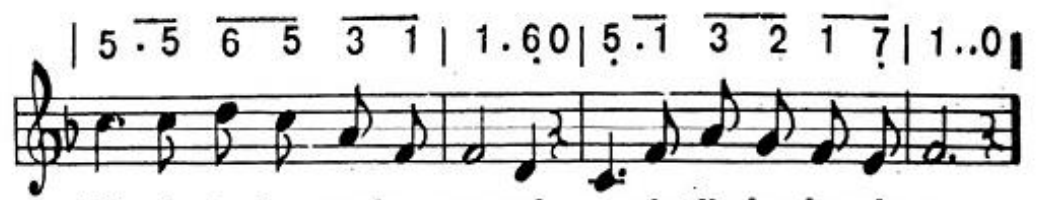

Ki-ni I - bu sedang susah, merintih dan berdo-a .

http://kwarcabkediri.blogspot.co.id 


\section{Tnimakasihken}

c+da $2 y+$

an Tuababo

Aad an be

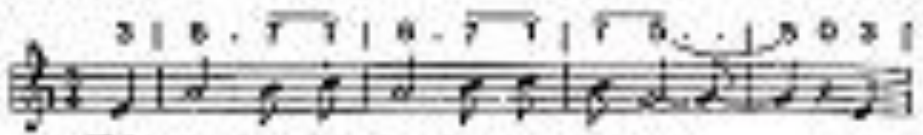

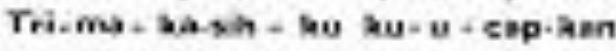

, Ba.

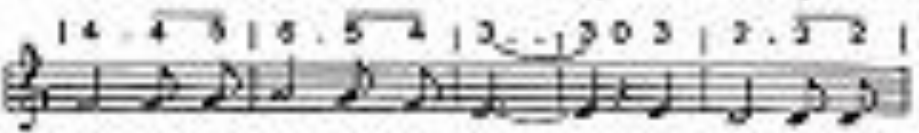

th pu-ru-ke vanglu-hur. II-mevang tast

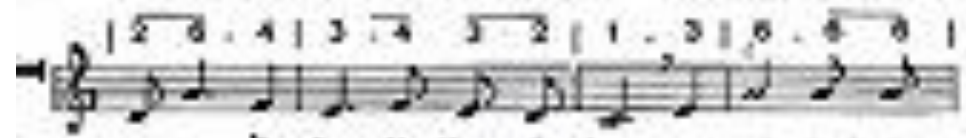

pu-na alla-lu di-limpal-kas, un-tuk bekd1-

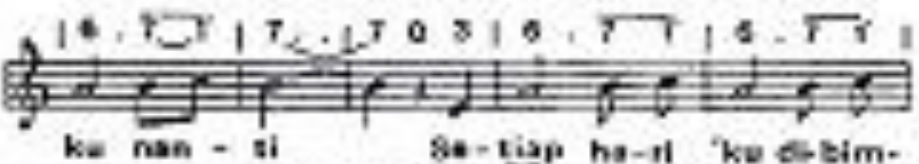

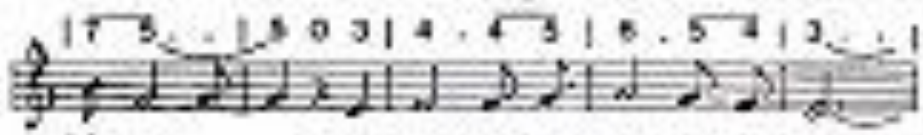

biagryb, A-por bumboh-lah barkst-ko

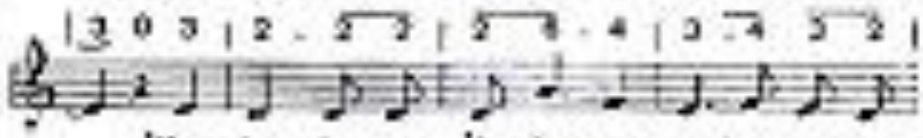
'Kan hu- iregat Lis-he no. se-hat guires

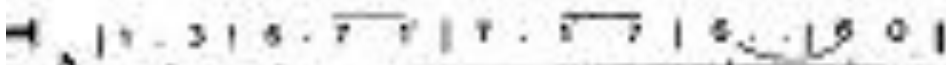

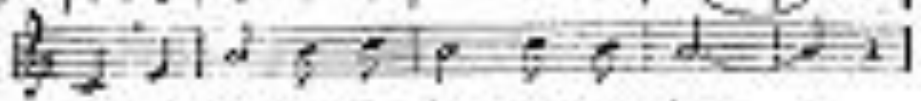
ku, Tri.ms-ka-sh bu $u$ - eap-kan 


\section{Gundhul Pacul}

$\mathrm{Do}=\mathrm{C}$

4/4 Moderato

Lagu Jawa Tengah

\begin{tabular}{l|lllllllllllllllll}
$1 \mid$ & 3 & 1 & 3 & 4 & 5 & 5 & 0 & 7 & 1 & 7 & 1 & 7 & 5 & 0 & 1
\end{tabular} \mid Gundhul-gu-dhul pa - cul-cul gem - be - leng - an, Nyung

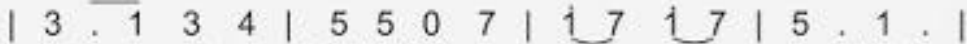
gi - nyunggi wa - kul-kul gem - be - leng - an, Wa -

| $3.5 .5 .\left|\begin{array}{llllllllllllll} & 3 & 4 & 4 & 5 & 4 & 3 & 1 & 4 & 3 & 1 & 1 & 0 & 1\end{array}\right|$ kul ngglim - pang se-ga - ne da-di sakla - tar, Wa

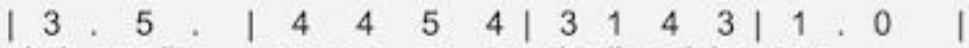
kul ngglim - pang se - ga - ne da-di sakla - tar 
Menanam Jagung

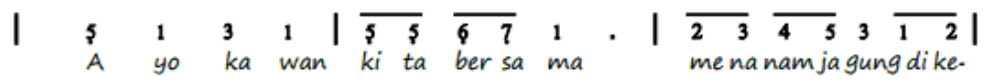

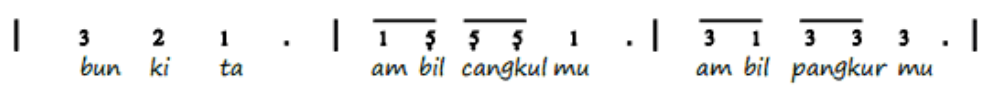

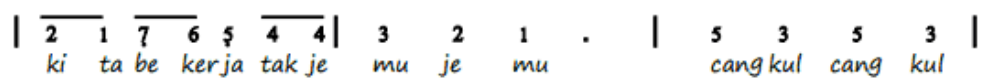

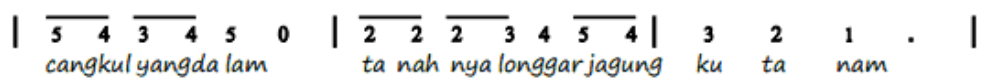

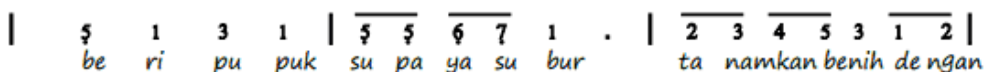

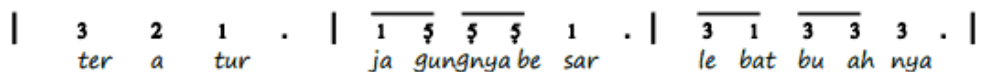

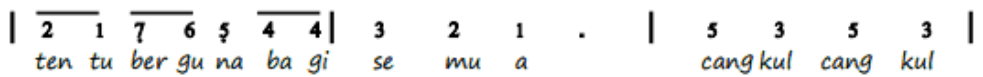

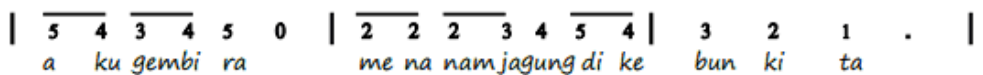




\section{Kampungku}

do $=$ C 3/4 Agak Cepat

Syair \& Lagu: A. T. Mahmud

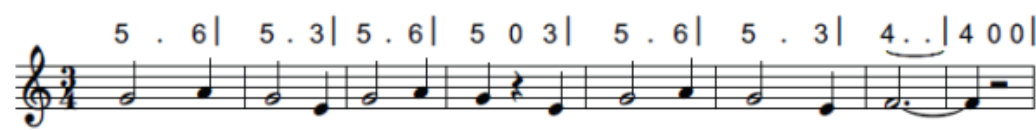

Kam - pung - ku te - pi su - ngai de - ngan ru - mah bam - bu

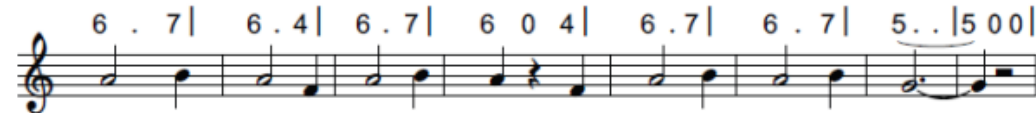

Kam - pung - ku te - pi su - ngai tem - pat lin - tas pra - hu

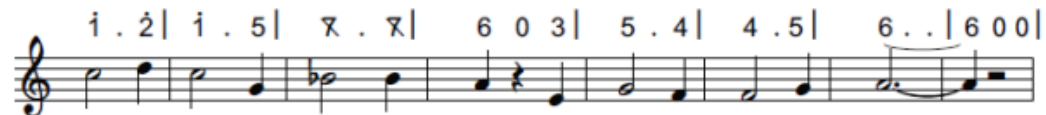

Di sa - na mu - lai kem - bang ra - sa ka - sih sa - yang

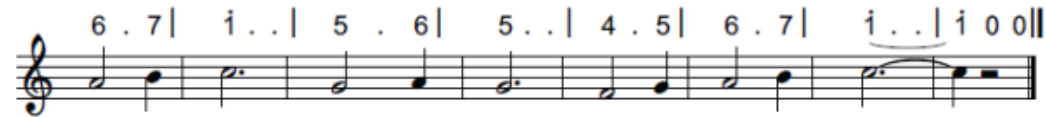

Pa - da - mu kam - pung - ku sla - lu ku - ke - nang

Sumber: Mahmud, A.T. 2008. Pustaka Nada 230 Lagu Anak-Anak Jakarta: Penerbit PI Grasindo 


\section{Burung Kutilang}

$1=\mathrm{C}$

$4 / 4$ Andante (100)

Teks a Laghe. Itru Sud.

$\mid$\begin{tabular}{l|ll}
34 & 5 & 5 \\
32
\end{tabular}

$\overline{12} \mid 3=-\overline{67}$

$i \overline{7} \overline{\bar{i}} \overline{76}$

Di-pe-euk pe-hen ee-ma- nu bes - rung ku-ti-lang ber-bu Swm-bil ber - lom- pat lom-pst-an pa-ruh - nys se-ta-lu ter-bu

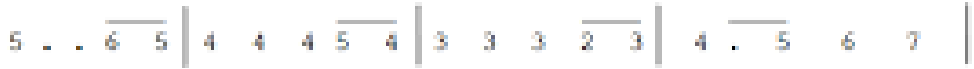
nyi ber-si-ul $2 \hat{-}$ - ul se-pan-jang ba- $r i$ de-ngan tais je - mu jeka di-ge-leng ge-leng-kan ke-ja - la - nya me-nen- tang is - ngit bi-

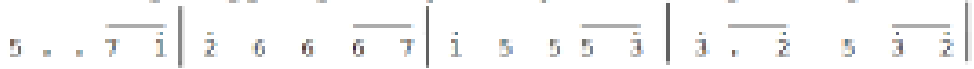

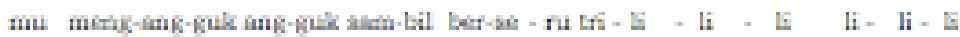
na tan-da-nya su-ka di-a ber-se-natri-li - L - li li- H- li i. .

11

li 


\section{Indonesia Pusaka}

Ismail Marzuki

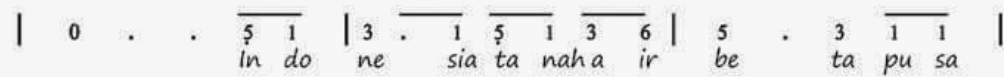

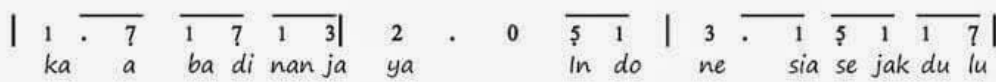

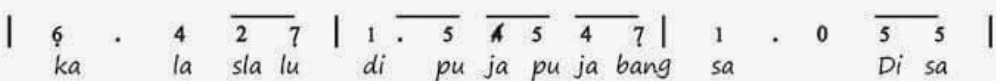

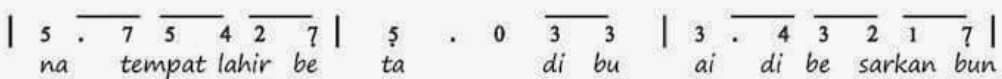

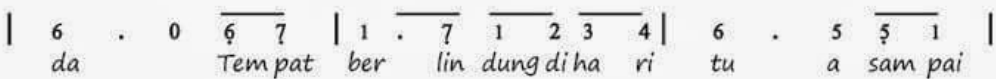

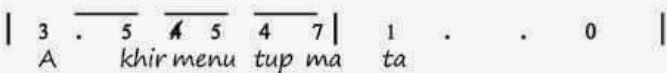


Do $=$ Bes

\section{Satu Nusa Satu Bangsa}

4/4, Andante maestoso
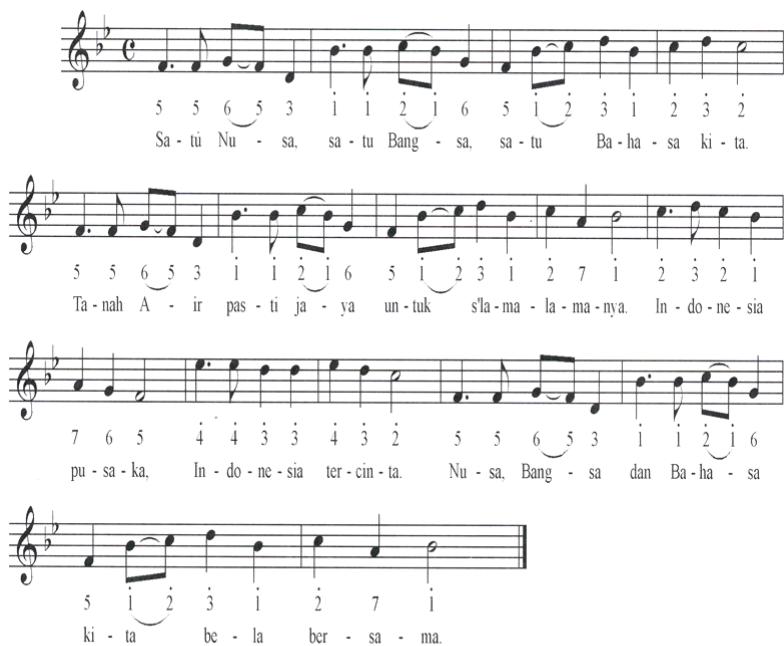


\section{TIMUR MATAHARI}

Do $=\mathrm{Es}$

W. R. Soepratman

4/4 Marcia

\begin{tabular}{llll|llll|llll|llll}
3 & 5 & 1 & 2 & 1 & $\cdot$ & 7 & $\cdot$ & 1 & 2 & 1 & 2 & 3 & $\cdot$ & $\cdot$
\end{tabular}

Di Ti - mur ma - ta - ri mu - lai ber-cah - ya

\begin{tabular}{|llll|llll|llll|lll}
4 & 3 & 4 & 5 & 7 & $\cdot$ & 6 & $\cdot$ & 5 & 6 & 4 & 3 & 2 & $\cdot$
\end{tabular}.

Ba-ngun dan ber-di - ri ka - wan se - mu - a

\begin{tabular}{llll|llll|llll|lll}
2 & 2 & 3 & 4 & 5 &. & 3 & $\cdot$ & 4 & 3 & 4 & 5 & 6 &. &.
\end{tabular}

$\mathrm{Ma} \cdot \mathrm{ri} \cdot \mathrm{lah} \mathrm{me} \cdot \mathrm{nga} \cdot \mathrm{tur}$ ba - ri - san ki - ta

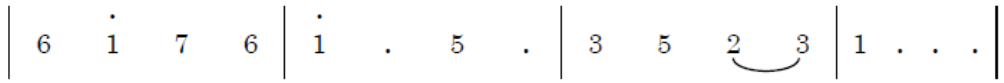

Se $\cdot$ lu - ruh pe $\cdot \mathrm{mu} \cdot \mathrm{da}$ In $\cdot$ do - ne - sia 


\section{Matahari Bersinar T'rang}

$E=1 ; 4 / 4$

(Nyanyian Pagi )

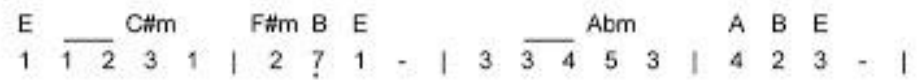

Ma-ta-ha-ri ber - si-nar trang. Bu-rung ber-ki-cau - lah se-nang.

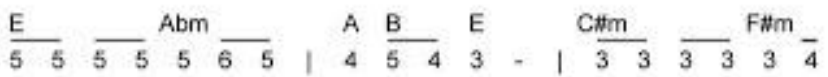

Ha-rum se-mer-bak-lah bu - nga di pa-dang. Se-mua-nya me-nga-jak

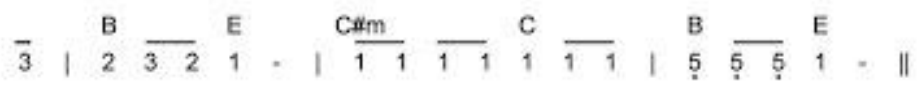

ke - pa-da ki-ta, 'kan me-mu-ji Na-ma Tu - han yg E-sa 
4/4 Do $=A($ Bes, As)

A. Simandjuntak

Gesit Tegas

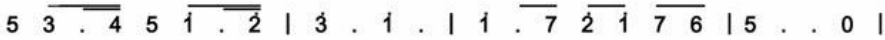

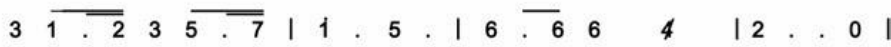

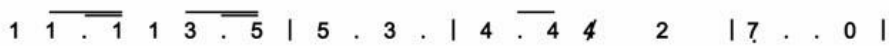

Ba-ngun pe-mu-di pe- mu- da In- do-ne- si - a

Su-di te- tap ber- $u$ - sa- ha ju- jurdan ikh - las

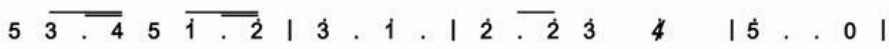

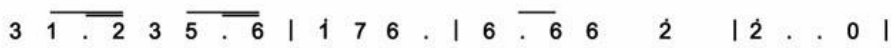

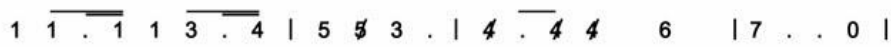

Ta-ngan ba-ju-mu sing- sing- kan un- tuk ne- ga ra.

Taku- sah banyak bi- ca- ra trus kerja ke- ras.

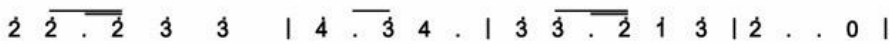

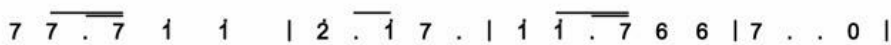

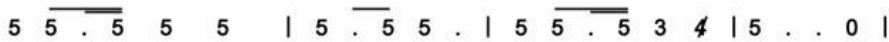

Ma-sa yang a- kan da- tang Ke- wa- ji- ban mu lah

$\mathrm{Ha}-\mathrm{ti}$ te-guh dan lu- rus Pi-kir te- tap jer- nih

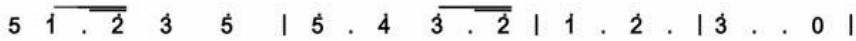

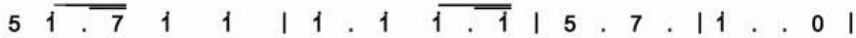

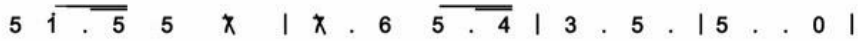

Men-ja- di tang- gung- an- mu ter- ha- dap Nu- sa

Ber-ting kah la- ku ha- lus hai $\mathrm{Pu}-$ tra $\mathrm{Ne}-$ gri

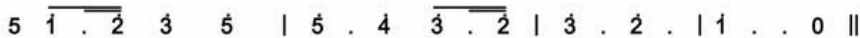

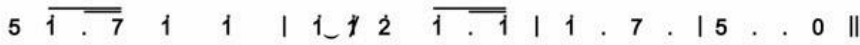

$5 \overline{1 . \overline{5}} 5 \times|\times .6 \overline{5 . \overline{4}}| 5.5 . \mid 3 . .6 \|$

Men-ja- di tang-gung- an- mu ter- ha- dap Nu- sa.

Ber-ting kah la- ku ha- lus hai Pu- tra Ne- gri. 
Do $=$ As

Selamal Dalang Pahlawan Muda

2/4, Marcia
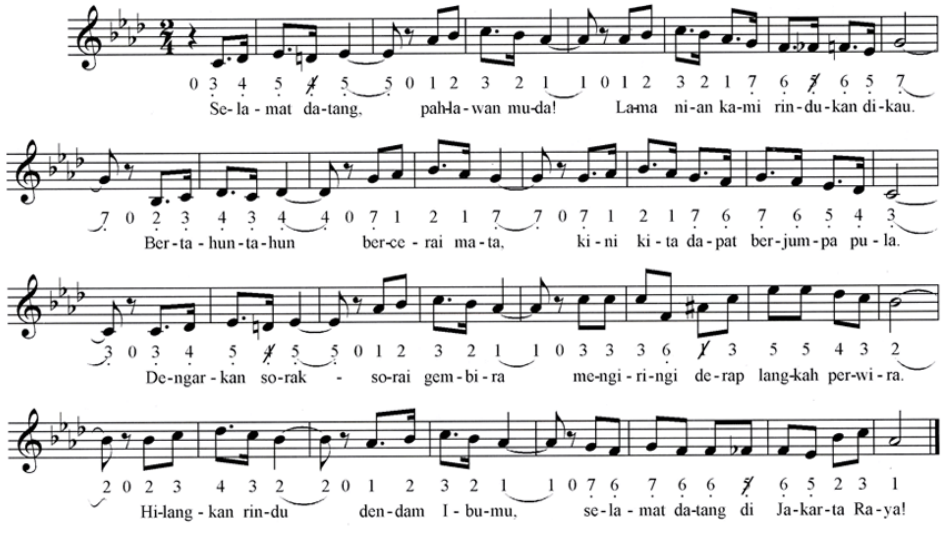


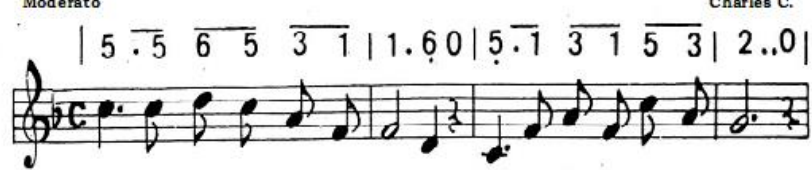

Ku- li-hat I- bu Per-ti-wi, sedang bersusah ha-ti .

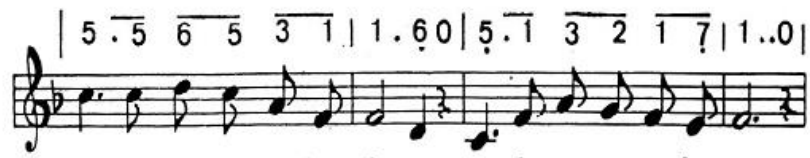

A - ir- ma-ta-mu ber-linang, masintanmu terkenang .

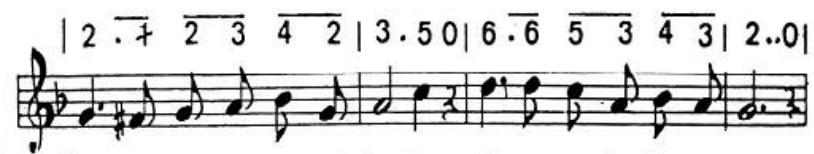

Hu-tan gunung sawah lautan, simpanan ke-kaya -an .

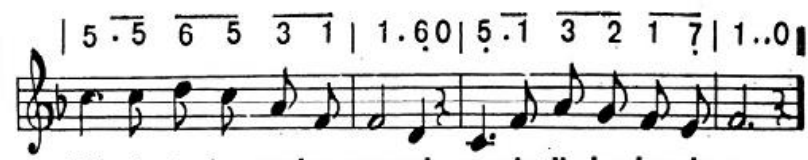

Ki-ni I - bu sedang susah, merintih dan berdo-a . http://kwarcabkediri.blogspot.co.id 


\section{Tnimakasihken}

c+da $2 y+$

ân Tolodo

Andate

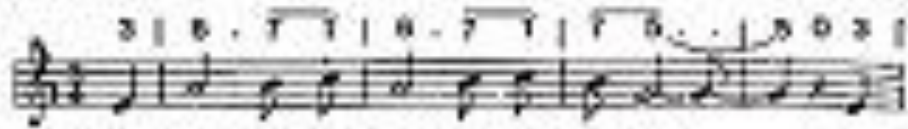

Triima- halsh - hu ku-u-enp-Aan

, Ba-

$0^{12-4515.52} 12--130312.52$ ।

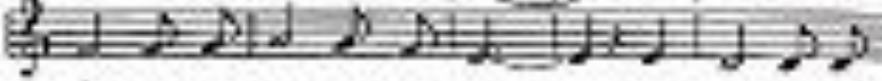

th pu-ru-kw vanglu-hur. II- mevang bar.

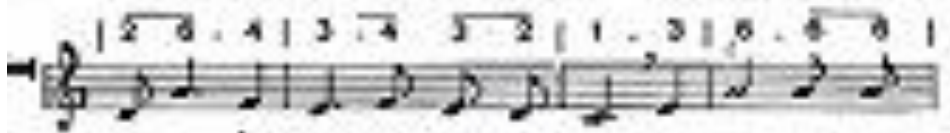

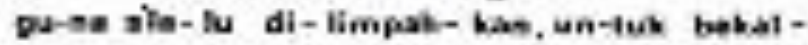

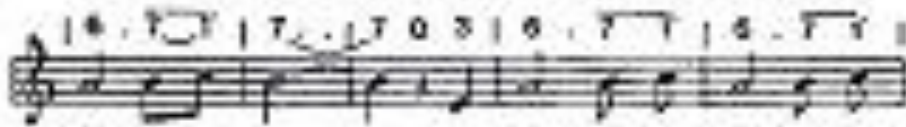
ke nan - si 8t-tiap ha-n " $\mathrm{ke}$ obteim-

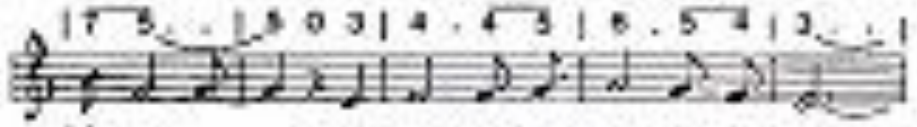
bingrya , A-por bumbeh-lah bathor-ko

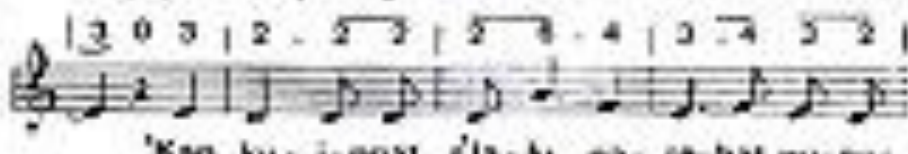
'Kan ha - ir mgat Lis-he nar sthat guires

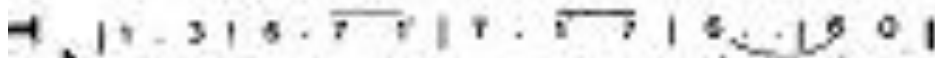

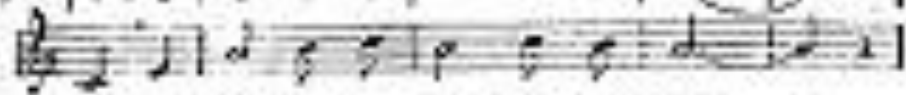
ku, Tri.ms-ka-sh be = u = eap-kan 


\section{Apuse}

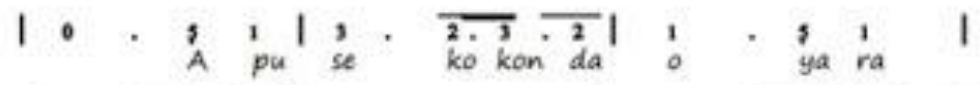

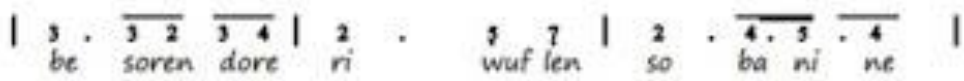

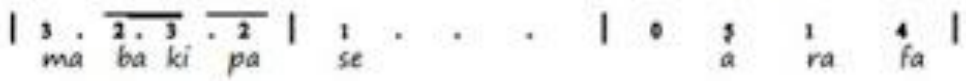

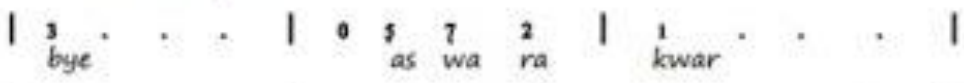

I. A 1 ra fa 1 bye 


$$
\mathrm{C}=\mathrm{do}
$$

\section{Cublak-cublak Sumeng}

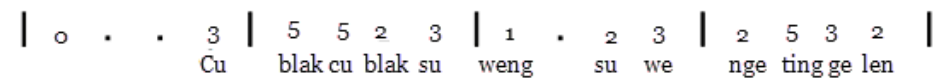

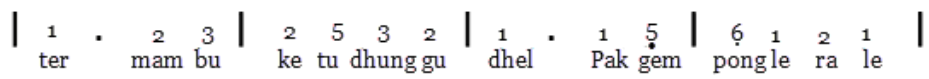

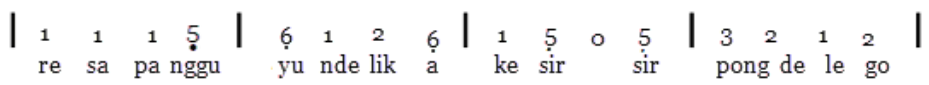

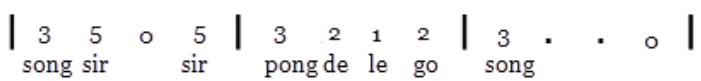




\section{KAMUS MUSIK}

Absolute pitch ( Pendengaran terlatih yang dapat

Perfect pitch ) mengetahui dan mengidentifikasikan nada.

Acapella Musik vokal tanpa diiringi instrument.

Accelerando Mempercepat tempo.

Accidentals

Tanda-tanda untuk menaikkan dan menurunkan nada.

Accompaniment Musik pengiring.

Singkatan dari Ad libitium, yaitu peluang

Ad lib yang diberikan kepada pemain instrument untuk memainkan instrument mereka secara bebas.

Al fine Sampai akhir.

Alto

Suara rendah pada wanita.

Analog

Alat elektronik yang tidak digital.

Arpegio

Uraian nada-nada dari chord yang berurutan naik dan turun.

A tempo

Kembali ke tempo awal.

Atonality

Membaikan kunci atau tonal center.

Augmented

Interval yang diperlebar.

- Pelopor / frontir.

Avant-garde

- Bermusik dengan cara yang tidak konvensional.

Bacbeat

Latar belakang irama/ ritme yang stabil. 
Ballad

Bar

Bar line

Baritone

Bass

Beat

Bending note

Brass section

Bridge

Brightly

Broken chord

Cadence

Cadenza

Changes

Chord
- Lagu bercerita.

- Lagu yang berirama lambat.

Pengelompokan ketukan-ketukan dalam hitungan genap atau ganjil.

Garis vertikal pemisah yang membatasi antara bar.

Pertengahan suara antara suara tenor dan bass pada vokal pria atau alat musik.

- Suara terendah dari vokal pria.

- Nada terendah pada musik.

- Ketukan teratur sebagai pedoman meterritme- dan tempo.

- Jenis irama musik- seperti Latin beat, Rock beat, dll.

Nada yang meliuk ( ciri khas dari musik blues ).

Kelompok pemain Brass bagian dari band.

Bagian transisi antara dua tema musik.

Dimainkan dengan gembira.

Arpegio chord yang dimainkan secara tidak beraturan.

Progression / resolution melodi atau harmoni yang menjadi konklusi sementara atau akhir.

Pemeragaan kemahiran tehknik bermain (improvisasi) oleh solis pada bagian akhir komposisi musik.

Pergerakan shord.

Harmonisasi tiga nada atau lebih. 
Chord

embellishment

Chordal tones

Chromatic

Clef

Coda

Common time

Consanance

Counterpoint

Crescendo

Da capo ( DC )

Diatonic

Diction

Diminished

Dissonance

Dominant

Double-stop
Memperindah harmoni dengan penambahan ornamentasi nada pada chord.

Nada-nada yang terdapat di dalam konstruksi chord.

Susunan / penggunaan melodic atau harmonik dari 12 nada.

Simbol yang menyatakan wilayah nada-nada pada staff, di sesuaikan dengan kebutuhan dan alat musik.

Bagian penutup dari musik.

Empat ketukan dalam satu bar.

Gabungan beberapa nada yang terdengar harmonis / enak.

Alur dua rangkaian melodi atau lebih secara bersamaan.

Suara menjadi keras secara bertahap.

Yaitu tanda yang menunjukan untuk mulai untuk memulai dari awal.

Berkenaan dengan tujuh major atau minor scale.

Cara mengucapkan kata pada penyanyi. Interval diperpendek.

Bunyi yang membuat rasa galau pada pendengaran.

Nada ke lima pada major / minor scale dan jenis chord yang terbentuk pada nada tersebut.

Dua nada dibunyikan serempak pada instrument string. 
Downbeat

Dragging

Duet/duo

Duplet

Dynamic

Encore (more)

Enharmonics

Ensemble

Falsetto

Fermata

Figured bass

Finale

Fingerboard

Fine (ending)

Glissando (gliss)

Grance note

Groove

Half-step

Harmony

Head
Ketukan pertama pada bar.

Tempo permainan yang menjadi lambat dari tempo yang seharusnya secara tanpa disengaja.

Komposisi yang menampilkan dua pemain.

Tiga ketuk dibagi dua dengan nilai tempo yang sama .

Berkenaan dengan volume dan kelembutan.

Istilah meminta pemain/ penyanyi untuk menambah lagi pergelarannya.

Satu nada dengan nama yang berbeda.

Kelompok pemain.

Suara tinggi vokal yang tidak umum.

Menahan nada/ chord / rest

Pola / bagian bass.

Tema penutup.

Tangkai ber-senar untuk jari pada instrument ber-string.

Akhir dari komposisi.

Memainkan scale pada piano dengan kecepatan tinggi.

Ornament nada yang singkat dan tidak memerlukan hitungan khusus.

"Fell" dari cara bermain dengan tempo "laid back" yang konstan dan stabil.

Jarak interval setengah nada.

Tentang perpaduan bunyi yang selaras.

Melodi lagu. 
Horn section

(brass section)

Interval

Inversion

Jam session

Key signature

Laidback

Leading tone

Legato

Ledger line

Licks

Measure

Mediant

Metronome

Microtone

Moderately

Modulation

Motif
Kelompok pemain alat tiup pada band.

Jarak antara dua nada.

Nada pada chord / interval yang dipindahkan

ke oktaf atas atau bawah, atau susunan

interval / chord terbalik.

Bermain musik dalam kelompok secara informal / tidak resmi.

Tanda accidentals pada permulaan staff untuk menentukan kunci.

Bermain sedikit diperlambat atau bermain dibelakang menentukan kunci.

Nada ketujuh pada diatonic scale.

Nada-nada dimainkan yang bersambung dengan tanda garis lengkung.

Garis bantu di atas dan di bawah staff.

Phrasing singkat atau klise phrasing yang dapat diidentifikasikan.

Hitungan pada sekelompok ketukan.

Nada ke tiga pada major atau minor scale.

Alat yang menyatakan / membunyikan jumlah ketukan per menit.

Jarak lebih kecil dari setengah nada ( half step ).

Dimainkan dengan kecepatan sedang (moderato).

Perubahan kunci.

Melodi singkat yang sangat khas. 
Non-chordal tones

Note

Octave

Overtone ( nada harmonik)

Overtone series

Part

Pedal point

Pentatonic

Perfect pitch

Phrase

Pitch

Quadruplet

Quartet

Quintet

Quintuplet

Real Book

Refrain
Nada-nada yang terletak di luar diatonic scale.

Simbol tertulis untuk nada.

Interval ke delapan dari diatonic scale.

Nada tambahan yang menyertai nada-nada biasa- biasanya terdapat di atas sebuah nada.

Serangkaian nada-nada overtone.

- Bagian dari komposisi musik.

- Bagian dari sebuah instrument tertentumisalnya guitar parts ( body, neck, head, tuning, dll...)

Nada bass yang ditahan, sementara harmoni berubah untuk menciptakan tensi.

Scale yang terdiri dari lima nada.

Bakat pendengaran yang sempurnasehingga dapat mengidentifikasikan atau mengetahui frekuensi suara.

Melodi singkat yang terbentuk dari beberapa motif.

Tinggi rendahnya nada atau suara.

Ketukan di bagi empat tuplet.

Kelompok empat pemain.

Kelompok lima pemain.

Ketukan di bagi dengan lima ketuk.

Buku kumpulan lagu-lagu standar.

Bagian dari komposisi lagu yang diulang beberapa kali. 
Resolution

Rest

Rhythm

Rhythm sections

Riff

Ritardando

Root

Rubato

Rushing

Scat-singing

Score

Semi-tone (mikro tone)

Septet
Pergerakan dari chord dissonance ke consonance.

Tanda istirahat - semua instrument musik tidak dimainkan .

Struktur musik yang berhubungan dengan ketukan tempo dan ketukan yang menyatakan fell atau penjiwaan sebuah lagu.

Kelompok pemain instrument yang merupakan bagian dari band. Rhythm section terdiri dari Guitar, Bass, Drum, dan Keyboard / piano.

Phrasing pendek yang diulang-ulang.

Kecepatan yang diperlambat secara bertahap.

Nada pertama scale atau nada dasar chord.

Teknik memainkan melodi tampa mematuhi nilai nada-nada agar dapat bermain dengan penuh perasaan.

Tempo permainan yang terburu-buru dan mendahului.

Vokal dengan menggunakan kata-kata yang tidak bermakna.

Notasi musik yang menjaqvarkan aransemen musik secara keseluruhan ( full score), dapat juga dalam bentuk vocal score atau orchestral score.

Frekwensi di antara interval half step.

Kelompok tujuh pemain. 
Septuplet

Sextuplet

Sharp

Shuffle

Slide (bending note)

Slowly

Slur

Solo

Soprano

Staccato

Staff

Standards

Step \& half

Subdominant

Submediant

Supertonic

Suspension
Ketukan dibagi tujuh tuplet.

Ketukan di bagi enam tuplet.

Tanda untuk menaikan nada half-step.

Irama Rock dengan fell Swing.

Nada yang dibelokkan atau bergeser.

Dimainkan dengan kecepatan lambat.

Garis lengkung yang menyatakan agar beberapa nada dapat dimainkan secara bersambung, atau sering juga di sebut Legato.

Komposisi untuk seorang pemain, sendiri atau diiringi .

Vokal wanita atau sebutan bagi alat musik dengan wilayah yang tinggi.

Nada pendek terputus, kebalikan dari Legato.

Lima garis sejajar untuk menulis nada.

Jenis lagu-lagu yang terpopuler di kalangan musik Jazz.

Jarak interval satu-setengah nada.

Nada keempat pada diatonic nada.

Nada keenam pada diatonic scale.

Nada kedua pada diatonic.

Non-chordal tone yang ditahan dari nada sebelumnya. 
Irama yang ditandai dengan aksen-aksen

Syncopation

Tempo

Tenor

Tetrachord

Timbre

Time signature

Tonality

Tone

Tonic

Tonging

Touch

Trade four

Transcription

Transposition

Tremolo

Triad

Trill kuat pada nada-nada yang semestinya beraksen lemah.

Kecepatan ketukan.

Wilayah tertinggi pada vokal pria.

Hubungan / urutan empat nada konsekutif ( tersusun) dari dua scale.

Kualitas atau warna suara / nada .

Bilangan pecahan pada permulaan staff.

Menyatakan bunyi atau warna suara.

Bunyi nada.

- Nada dasar dari komposisi musik.

- Nada pertama dari scale.

Pengaturan posisi lidah pada alat musik tiup.

Gaya dan daya sentuh pemain khususnya untuk Keyboard dan instrument ber-senar.

Tradisi bepop dalam improvisasi- bergantian anatara drums dan instrument lainnya pada tiap-tiap empat bar.

Musik yang tertulis atau disebut juga sheet music.

Menulis kembali atau memainkan musik dengan mengubah tingkat nadanya.

Tehknik memainkan perulangan nada dengan sangat cepat.

Chord tiga nada.

Perulangan cepat dari sebuah nada yang diselingi dengan nada terdekat diatasnya. 
Trio

Triple time

Triplet

Tune

Tuner

Tuning fork (garpu tala)

Tuplet

Tutti

Unison

Up beat

Upright piano

Vibrato

Waltz

Whole step (whole tone)

Yodel
Kelompok tiga pemain.

Pembagian tempo ke dalam tiga ketukan.

Satu ketuk atau ketukan genap yang dibagi tiga dengan nilai yang sama rata .

- Lagu atau melodi.

- Harmonis atau selaras (in tune).

Alat untuk menyelaraskan nada.

Batang yang terbuat dari logam dan berbentuk huruf ' $U$ ' bertangkai untuk menala nada.

Pembagian ketukan.

Semua pemain memainkan hal yang sama.

Nada yang sama dimainkan oleh dua pemain atau lebih.

- Ketukan yang berada di atasa hitungan.

- Gerak tangan dirigen ke atas.

Jenis piano dengan senar-senar

terentangkan berdiri tegak.

Nada yang bergetar / teknik menggetarkan nada.

Ketukan tiga perempat.

Jarak interval satu nada.

Teknik menyanyi diselingi dengan suarasuara falsetto (ciri khas musik country western). 


\section{BIODATA}

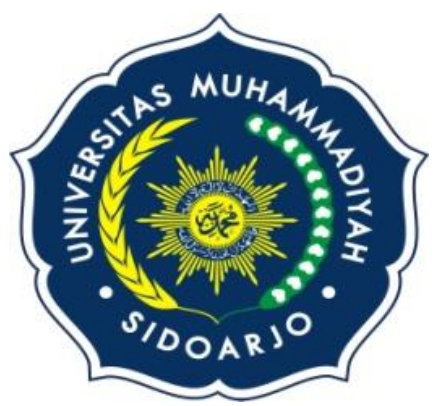

UMSIDA PRESS

Evie Destiana, alumni Etnomusikologi Institut Seni Indonesia Yogyakarta dan Magister Pendidikan Seni Budaya UNESA kelahiran Surabaya, 7 Desember 1980. Aktif dalam kegiatan seni di Surabaya, merupakan salah satu pelatih paduan suara UPT PPTK Balai Pelatihan Seni Jawa Timur. Saat ini penulis tercatat sebagai dosen tetap di Universitas Muhammadiyah Sidoarjo. Penulis juga aktif

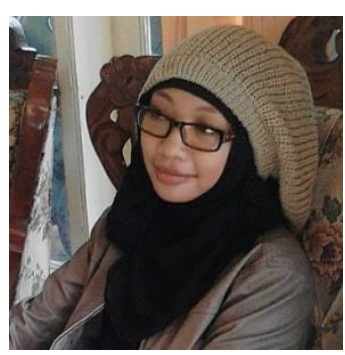
dalam memberikan pelatihan musik bagi guru-guru PAUD di Sidoarjo. Saat ini penulis sedang menyelesaikan buku ajar musik untuk AUD sebagai buku pendamping dalam pembelajaran musik bagi guru-guru PAUD. Bagi pembaca yang ingin menghubungi penulis dapat melalui email : eviedestiana@umsida.ac.id . , 


\section{DAFTAR PUSTAKA}

Banoe, Pono. 2003. Teori Dan Pengetahuan Umum Musik, Pengantar Pengetahuan Harmoni. Yogyakarta: Kanisius.

Beawata. 1991. Ensiklopedia Nasional Indonesia 15, Jakarta: PT. Cipta pustaka.

Creswell, John W, 2010. Designing and Conducting Mixed Metod.

Ellys J. 2005. Kiat Mengasah Kecerdasan Emosional Anak. Bandung : Pustaka Hidayah.

Goleman, Daniel. 2004. Emotional Intelligence. Jakarta : Gramedia Pustaka Utama.

Kumpulan Artikel Kompas. 2001. Mencetak Anak Cerdas dan Kreatif. Jakarta: Kompas.

Mahmud, AT. 1995. Musik dan Anak. Jakarta : Departemen Pendidikan dan Kebudayaan.

M. Ortiz. 2002. Menumbuhkan Anak-anak Yang Bahagia, Cerdas dan Percaya Diri Dengan Musik. Jakarta : Gramedia Pustaka Utama.

Patmono Dewo, Soemiarti. 1995. Buku Ajar Pendidikan Pra 
Sekolah. Jakarta : Departemen Pendidikan dan Kebudayaan Direktorat Jenderal Pendidikan Tinggi Proyek Pendidikan Tenaga Akademik.

Prier, Karl Edmund, 1998. Ilmu Bentuk Musik. Yogyakarta: Pusat Musik Liturgi.

Prier, Karl Edmund, 2011. Kamus Musik. Yogyakarta: Pusat Musik Liturgi

Sujiono, Bambang dan Nurani Yuliani. 2005. Mencerdaskan Perilaku Anak Usia Dini. Jakarta : Gramedia. 